\title{
Seasonal Variation and Sources of Carbonaceous Species and Elements in PM2.5 and PM10 Over the Eastern Himalaya
}

\section{Sudhir Kumar Sharma ( $\nabla$ sudhir@nplindia.org )}

CSIR-National Physical Laboratory, Dr. K. S. Krishnan Road, New Delhi-110 012, India https://orcid.org/0000-0003-2268-3933

\section{Sauryadeep Mukherjee}

Bose Institute

\section{Nikki Choudhary}

CSIR-National Physical Laboratory: National Physical Laboratory CSIR

\section{Akansha Rai}

CSIR-NPL: National Physical Laboratory CSIR

Abhinandan Ghosh

Bose Institute

\section{Abhijit Chatterjee}

Bose Institute

\section{Narayanswami Vijayan}

CSIR-National Physical Laboratory: National Physical Laboratory CSIR

Tuhin Kumar Mandal

CSIR-National Physical Laboratory: National Physical Laboratory CSIR

\section{Research Article}

Keywords: PM2.5, PM10, OC, EC, WSOC, Elements, PCA

Posted Date: February 9th, 2021

DOI: https://doi.org/10.21203/rs.3.rs-168623/v1

License: (c) (1) This work is licensed under a Creative Commons Attribution 4.0 International License. Read Full License 
1 Seasonal variation and sources of carbonaceous species and elements in $\mathbf{P M}_{2.5}$ and $\mathbf{P M}_{10}$ over the eastern Himalaya

3

4 Sudhir Kumar Sharma ${ }^{1,2^{*}}$ - Sauryadeep Mukherjee ${ }^{3}$ - Nikki Choudhary ${ }^{1,2}$ - Akansha Rai ${ }^{1,2}$ • Abhinandan Ghosh ${ }^{3}$.

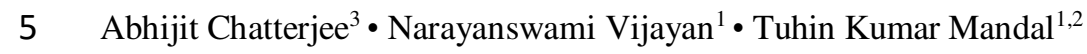

6

$7 \quad{ }^{1}$ CSIR-National Physical Laboratory, Dr. K. S. Krishnan Road, New Delhi-110 012, India.

$8 \quad{ }^{2}$ Academy of Scientific and Innovative Research (AcSIR), Ghaziabad-201 002, India

$9 \quad{ }^{3}$ Centre for Astroparticle Physics and Space Sciences, Bose Institute, Darjeeling-734 102, India.

10

11

12

13

14

$15 *$ Author's to Correspond:

16

17

18

19

20

21

22

23

24

25

Sudhir Kumar Sharma

Environmental Sciences and Biomedical Metrology Division

CSIR-National Physical Laboratory

Dr. K S Krishnan Road

New Delhi-110 012, India

E-mail: sudhir.npl@nic.in; sudhircsir@gmail.com

Phone: +91-11-45609448

Fax: +91-11-45609310

26

27

28

29 


\section{Abstract}

31 The study represents the seasonal characteristics (carbonaceous aerosols and elements) and contribution of 32 prominent sources $\mathrm{PM}_{2.5}$ and $\mathrm{PM}_{10}$ in the high altitude of the eastern Himalaya (Darjeeling) during August 201833 July 2019. Carbonaceous aerosols [organic carbon (OC), elemental carbon (EC) and water soluble organic carbon 34 (WSOC)] and elements (Al, Fe, Ti, Cu, Zn, Mn, Cr, Ni, Mo, Cl, P, S, K, Zr, Pb, Na, Mg, Ca, and B) in PM 2.5 and $35 \mathrm{PM}_{10}$ were analyzed to estimate their possible sources. The annual average concentration of $\mathrm{PM}_{2.5}$ and $\mathrm{PM}_{10}$ were 36 computed as $37 \pm 12 \mu \mathrm{g} \mathrm{m}^{-3}$ and $58 \pm 18 \mu \mathrm{g} \mathrm{m}^{-3}$, respectively. In the present case, total carbonaceous species in $\mathrm{PM}_{2.5}$ 37 and $\mathrm{PM}_{10}$ were accounted for $20.6 \%$ of $\mathrm{PM}_{2.5}$ and $18.6 \%$ of $\mathrm{PM}_{10}$, respectively. Whereas, trace elements in $\mathrm{PM}_{2.5}$ 38 and $\mathrm{PM}_{10}$ were estimated as $15 \%$ of $\mathrm{PM}_{2.5}$ and $12 \%$ of $\mathrm{PM}_{10}$, respectively. Monthly are seasonal variations in 39 concentrations of carbonaceous aerosols and elements in $\mathrm{PM}_{2.5}$ and $\mathrm{PM}_{10}$ were also observed during the observational period. The positive relationship between OC \& EC and OC \& WSOC of $\mathrm{PM}_{2.5}$ and $\mathrm{PM}_{10}$ during all

41 the seasons (except monsoon in case of $\mathrm{PM}_{10}$ ) indicate rheir common sources. The enrichment factors (EFs) and 42 significant positive correlation of $\mathrm{Al}$ with othe crustal elements ( $\mathrm{Fe}, \mathrm{Ca}, \mathrm{Mg}$ and $\mathrm{Ti}$ ) of fine and coarse mode 43 aerosols indicates the influence of mineral dust at the Darjeeling. Principal component analysis (PCA) resolved the 44 four common sources (biomass burning + fossil fuel combustion (BB+FFC), crustal/soil dust, vehicular emissions 45 (VE) and industrial emissions (IE)) of $\mathrm{PM}_{2.5}$ and $\mathrm{PM}_{10}$ in Darjeeling.

46

47 Keywords: $\mathrm{PM}_{2.5}, \mathrm{PM}_{10}$, OC, EC, WSOC, Elements, PCA 


\section{Introduction}

The urban agglomeration of hilly region of India is under serious threat various forms of anthropogenic activities and pollutants (Gajananda et al. 2005; Sharma et al. 2020a;b). Due to rapid urbanization, industrialization, increasing vehicular traffic due to increased tourism-related activities, increase in energy demands (for lighting, cooking and heating etc.) have resulted in contamination/deterioration of ambient air quality, vegetation and climate of the hilly region (Chatterjee et al. 2010; Rai et al. 2020a). From last few decades the fine and coarse mode of aerosol/particulate matter (PM) has been altered the atmospheric particle chemistry, Earth's climate system (radiative balance), and human health (Pant and Harrison 2012; Bond et al. 2013). Therefore, quantification and identification of chemical species and sources of aerosol is essential to explore the appropriate mitigation option to improve the ambient air quality, human health and climate (Ramana et al. 2010; Cao et al. 2006; Bond et al. 2013; Pope et al. 2009; Ramgolam et al. 2009; Sharma et al. 2018 a; b; Rai et al., 2020b).

Carbonaceous aerosols (CAs) are the major fractions (OC, and EC) of $\mathrm{PM}_{2.5}$ and $\mathrm{PM}_{10}$ in the atmosphere and have significant role in the Earth's radiative balance, visibility degradation, alteration of atmospheric chemistry (Lim and Turpin 2002; Hansen et al. 2005; Bond et al. 2013; Pope et al. 2009). Various toxic gases $\left(\mathrm{CO}, \mathrm{CO}_{2}, \mathrm{SO}_{\mathrm{x}}\right.$, $\mathrm{NH}_{3}$, and NOx, etc.,) organics and hydrocarbons (like, VOCs: volatile organic compounds; PAHs: polycyclic aromatic hydrocarbons) are produced during the combustion process/emissions of CAs and therefore affect the respiratory/cardiovascular system of the human (Lighty et al. 2000; Pope et al. 2009). Both primary and secondary organic aerosols significantly control of physico-chemical properties of particles/aerosols (Kanakidou et al. 2005) and influenced the formation cloud condensation nuclei $(\mathrm{CCN})$, whereas EC absorb solar radiation and contribute for radiative change (Bond et al., 2013).

PM consists of organics (OC, EC, and other components), mineral/crustal/soil dust, metals, non-metals, inorganic pollutants as well as sea salts and relative exuberance of these components are highly variable both spatially and temporally (Ram et al. 2011; Jain et al. 2017). Generally, the elements linked with the PM are nonvolatile in nature and remain unaffected even though they go for regional as well as long-range transportation (Morawska and Zhang, 2002). Some of the transition/toxic metals (like Fe, $\mathrm{Cu}, \mathrm{Mn}, \mathrm{Zn}, \mathrm{Ni}, \mathrm{Cr}, \mathrm{As}, \mathrm{Pb}, \mathrm{Hg}$ ) which are coming from the various sources into the ambient air have acute toxic and mutagenic effects on human health, when inhaled at higher concentrations. Elements like $\mathrm{Fe}, \mathrm{Al}, \mathrm{Si}, \mathrm{Ca}$ and $\mathrm{Ti}$ are also available in the fine and coarse mode PM is originated from mineral dust/crustal dust (Sharma et al. 2014a). Soluble K in PM mostly originated 
from biomass burning, however, it is also attributed to dust in PM (Viana et al. 2008), whereas $\mathrm{Cl}$ originated from sea salt is also considered from coal burning in aerosols (Pant and Harrison 2012).

Several studies conducted in past on carbonaceous aerosols, inorganic aerosols and elements in particulate matter and their potential sources in urban (Ram and Sarin, 2011; Mandal et al. 2014; Sharma et al. 2016; Gupta et al. 2018; Shivani et al. 2019; Jain et al. 2020a;b), rural, remote (Begam et al. 2017) as well as high altitude atmosphere (Ram et al. 2008; Kumar and Attri, 2016; Sarkar et al. 2017; Kaushal et al. 2018) but very limited study (Sharma et al. 2020b) has been conducted in the eastern Himalayan region of India. Considering the importance of atmospheric carbonaceous species and elements in $\mathrm{PM}_{2.5}$ and $\mathrm{PM}_{10}$ and from their perspective on climate change, the present study has been carried out at Darjeeling (the eastern Himalaya). In this paper, we report the carbonaceous components (OC, EC, and WSOC) and elements (Al, Fe, Ti, Cu, Zn, Mn, Cr, Ni, Mo, Cl, P, S, K, Zr, $\mathrm{Pb}, \mathrm{Na}, \mathrm{Mg}, \mathrm{Ca}$, and $\mathrm{B}$ ) of $\mathrm{PM}_{2.5}$ and $\mathrm{PM}_{10}$ over the eastern Himalaya (Darjeeling) during August 2018 - July 2019. Principal component analysis (PCA) and HYSPLIT trajectory were applied to resolve the potential sources and source region, respectively of $\mathrm{PM}_{2.5}$ and $\mathrm{PM}_{10}$ at Darjeeling.

\section{Materials and methods}

\subsection{Description of study site}

The study was carried out in the campus of Bose Institute, Darjeeling $\left(27.01^{\circ} \mathrm{N}\right.$ and $88.15^{\circ} \mathrm{E} ; 2200 \mathrm{~m}$ asl) situated in the Eastern Himalaya (Fig. 1). The hilly districts of Darjeeling are situated within the lower and subHimalayan ranges of the eastern Himalaya. Darjeeling is surrounded by Sikkim Himalayas, Bhutan Himalaya and Nepal Himalaya from the north, east and west sides, respectively (Chatterjee et al. 2021). The study area is considered as a semi-urban and is under he influence of biomass burning, vehicle emissions, agriculture and tourism activities (Adak et al. 2014). The climate of Darjeeling is subtropical and temperate with wet summer/pre-monsoon and monsoonal rains (June-September). The annual average maximum temperature was estimated to be $12.2{ }^{\circ} \mathrm{C}$ (in summer: March-May) whereas the average minimum temperature was estimated as $3.4{ }^{\circ} \mathrm{C}$ (in winter: JanuaryFebruary) with monthly mean temperatures ranging from 5.8 to $17.2{ }^{\circ} \mathrm{C}$. The monthly average meteorology (ambient temperature, relative humidity (RH), wind speed and wind directions) during the study period are depicted in Fig. S1 (see the supplementary information). The detail information on topography, weather, township and influences of local pollution sources at the study site is described in Chatterjee et al. (2021). 
106

107

108

109

\subsection{Sample collection and analysis}

$\mathrm{PM}_{2.5}(n=94)$ and $\mathrm{PM}_{10}(n=102)$ samples were collected simultaneously on pre-combusted $\left(\right.$ at $\left.550{ }^{\circ} \mathrm{C}\right)$ Pallflex tissue quartz filters (47mm for $\mathrm{PM}_{2.5}$ and $20 \times 25 \mathrm{~cm}^{2}$ for $\mathrm{PM}_{10}$ ) using Fine Particle Sampler (flow rate: $1 \mathrm{~m}^{3}$ $\mathrm{h}^{-1} \pm 2 \%$ ) and Respirable Particle Sampler (flow rate: $1.2 \mathrm{~m}^{3} \min ^{-1} \pm 2 \%$ ), respectively for $24 \mathrm{~h}$ from August 2018July 2019 ( $\mathrm{PM}_{2.5}$ sampling was not carried out in July 2019). The particle sampler was placed on the rooftop of the Bose Institute at the height of $15 \mathrm{~m}$ above the ground level. The gravimetric mass (in $\mu \mathrm{g}$ ) of $\mathrm{PM}_{2.5}$ and $\mathrm{PM}_{10}$ was computed by the difference between the initial and final weight using a calibrated weighing balance (M/s. Sartorius, resolution: $\pm 10 \mu \mathrm{g}$ ) of the filter. The concentrations of $\mathrm{PM}_{2.5}$ and $\mathrm{PM}_{10}\left(\right.$ in $\mu \mathrm{g} \mathrm{m} \mathrm{m}^{-3}$ ) were further computed by dividing the PM mass to the total volume of air passed during the sampling period (24h). Before chemical analysis the samples were stored at $-20^{\circ} \mathrm{C}$.

The concentrations of $\mathrm{OC}$ and $\mathrm{EC}$ in $\mathrm{PM}_{2.5}$ and $\mathrm{PM}_{10}$ samples were estimated by $\mathrm{OC} / \mathrm{EC}$ Carbon analyzer (Model: DRI 2001A; Make: Atmoslytic Inc., Calabasas, CA, USA) using IMPROVE-A Protocol (Chow et al. 2004). OC/EC carbon analyzer is working on the preferential oxidation of OC and EC at different temperatures plateaus $\left(140,280,480\right.$ and $580^{\circ} \mathrm{C}$; for $\mathrm{OC} 1, \mathrm{OC} 2, \mathrm{OC} 3$ and $\mathrm{OC} 4$, respectively) in pure helium and three temperature plateaus $\left(580,740\right.$ and $840^{\circ} \mathrm{C}$ for $\mathrm{EC} 1, \mathrm{EC} 2$ and $\mathrm{EC} 3$, respectively) in $98 \%$ helium and $2 \%$ oxygen (Chow et al. 2004). A proper punch of $\sim 0.536 \mathrm{~cm}^{2}$ area of the filter was cut and analyzed in triplicate along with field blank filters. The standard calibration for peak area verification was performed daily using $5 \% \mathrm{CH}_{4}+$ balance helium gas (before and after sample analysis). Calibration of the OC/EC analyzer was performed by $4.8 \%$ of $\mathrm{CO}_{2}+$ balance He gas along with known amounts of KHP (potassium hydrogen phthalate) and sucrose solution (Sharma et al. 2020b). In the present case, repeatability error of OC and EC analysis were estimated as 3-7\% (n=3). Total carbonaceous aerosols (TCA) of $\mathrm{PM}_{2.5}$ and $\mathrm{PM}_{10}$ are computed as (1.6×OC)+EC (Rengarajan et al. 2007; Srinivas and Sarin 2014).

A known punch size of $\mathrm{PM}_{2.5}\left(\sim 3.46 \mathrm{~cm}^{2}\right)$ and $\mathrm{PM}_{10}\left(\sim 7.07 \mathrm{~cm}^{2}\right)$ filters were cut into four halves and was soaked in $20 \mathrm{ml}$ of de-ionized water $(18.2 \mathrm{M} \Omega-\mathrm{cm})$ and ultrasonicated three times for $10 \mathrm{~min}$ each. The $10 \mathrm{ml}$ filtered extract was transferred into a pre-cleaned glass vial and analyzed for WSOC and WIOC using a TOC analyzer operating on catalytically-aided combustion oxidation (Model: Shimadzu TOC-L CPH/CPN, Japan). Field blank filters were also analyzed using the same analytical procedure and subtracted from the respective $\mathrm{PM}_{2.5}$ and $\mathrm{PM}_{10}$ 
samples to obtain the analytical results (WSOC and WIOC $=$ OC-WSOC)). Calibration of the instrument was performed before analysis of the samples using standard solution of five different concentrations. 3-10\% of repeatability errors were estimated in WSOC analysis $(n=3)$. The detail, analytical procedures is described in Rai et al. (2020a).

Wavelength Dispersive X-ray Fluorescence Spectrometer (WD-XRF) was used to analyzed the concentrations of $\mathrm{Al}, \mathrm{Fe}, \mathrm{Ti}, \mathrm{Cu}, \mathrm{Zn}, \mathrm{Mn}, \mathrm{Cr}, \mathrm{Ni}, \mathrm{Mo}, \mathrm{Cl}, \mathrm{P}, \mathrm{S}, \mathrm{K}, \mathrm{Zr}, \mathrm{Pb}, \mathrm{Na}, \mathrm{Mg}, \mathrm{Ca}$, and $\mathrm{B}$ in $\mathrm{PM}_{2.5}$ and $\mathrm{PM}_{10}$ (with repeatability errors 5-10\%). The samples were analyzed in triplicate and for major and trace elements. The detail, analytical procedures is available in Jain et al. (2020a;b).

\subsection{Primary organic carbon (POC) and secondary organic carbon (SOC)}

The concentrations of $\mathrm{POC}$ in $\mathrm{PM}_{2.5}$ and $\mathrm{PM}_{10}$ samples are estimated using minimum OC/EC ratio for the each season (winter, summer, monsoon and post-monsoon). Both OC and EC in ambient aerosols are considered to be originated from combustion sources and EC is a good marker for POC (Castro et al. 1999). POC are computed using the following equation,

$$
\mathrm{POC}=[\mathrm{OC} / \mathrm{EC}]_{\min } \times[\mathrm{EC}]+\mathrm{c}
$$

where, $\mathrm{c}$ is the contribution from non-combustion sources which is negligible in the present case. SOC is estimated as the difference of $\mathrm{OC}$ and $\mathrm{POC}(\mathrm{SOC}=\mathrm{OC}-\mathrm{POC})$.

\subsection{Enrichment Factors (EFs)}

Crustal EFs referes the origin of the elements (either anthropogenic or natural) and their abundance in the ambient particulates (Amato et al., 2016). The EFs of the elements present in $\mathrm{PM}_{2.5}$ and $\mathrm{PM}_{10}$ samples are computed (Taylor and McLennan, 1995) as:

$$
\mathrm{EF}=\frac{E l_{\text {sampl }} / \mathrm{X}_{\text {sample }}}{\mathrm{El}_{\text {cruss }} / \mathrm{X}_{\text {sanple }}}
$$

where,

$\mathrm{El}_{\text {sample }}=$ element $(\mathrm{El})$ mass concentration

$\mathrm{X}_{\text {sample }}=$ reference element $(\mathrm{X})$ mass concentration

$\mathrm{El}_{\text {crust }}=$ element $(\mathrm{El})$ concentration in upper continental crust

$\mathrm{X}_{\text {crust }}=$ reference element $(\mathrm{X})$ concentration in upper continental crust 
Aluminium (Al) is used as the reference element in this study, which is also supported by the previous studies (Sharma et al. 2014a; 2020b).

\subsection{Principal component analysis (PCA)}

In this study, PCA was applied on chemical constituents of $\mathrm{PM}_{2.5}$ and $\mathrm{PM}_{10}$ to identify the potential sources contributing to fine and coarse fractions aerosols. It uses orthogonal decomposition to identify individual groups of components which are then tied to variables by loading factors (Viana et al. 2008). The total variability of the data sets is shared between these components, whereas the maximum is shared by the first component (Belize et al. 2013). In PCA, the chemical data are transformed into a dimensionless standardized form:

$$
Z i j=\frac{C i j-\overline{C j}}{\sigma j}
$$

where $i=1, \ldots$, n samples; $j=1, \ldots m$ elements; $C i j$ is the concentration of element $j$ in sample $i$; and $\overline{C j}$ and $\sigma j$ are the arithmetic mean concentration and the standard deviation for element $j$, respectively. The PCA model is expressed as:

$$
\mathrm{Z}_{\mathrm{ij}=} \sum_{k=1}^{p} g_{i k} h_{k j}
$$

Where $\mathrm{k}=1, \ldots, p$ sources, and $g_{i k}$ and $h_{k j}$ are the factor loadings and the factor scores, respectively. This equation is solved by Eigenvector decomposition (Song et al. 2006).

\section{Results and discussion}

\subsection{Seasonal variations of chemical species of $\mathbf{P M}_{2.5}$ and $P M_{10}$}

\subsubsection{Seasonal variability of $P M_{2.5}$ and $P M_{10}$}

The annual average $\mathrm{PM}_{2.5}$ and $\mathrm{PM}_{10}$ concentrations were estimated as $37 \pm 12 \mu \mathrm{g} \mathrm{m}{ }^{-3}$ (range: $16-77 \mu \mathrm{g} \mathrm{m}^{-3}$ ) and $56 \pm 18 \mu \mathrm{g} \mathrm{m}^{-3}$ (range: $21-116 \mu \mathrm{g} \mathrm{m}^{-3}$ ), respectively (Table 1 ). The maximum monthly average mass concentration of $\mathrm{PM}_{2.5}$ was recorded in October $\left(58 \mu \mathrm{g} \mathrm{m}^{-3}\right)$ and the minimum monthly average concentration of $\mathrm{PM}_{2.5}$ was observed in January $\left(27 \mu \mathrm{g} \mathrm{m}^{-3}\right)$. Whereas, monthly average maxima of $\mathrm{PM}_{10}$ was observed in March $\left(73 \mu \mathrm{g} \mathrm{m}^{-3}\right)$ and monthly average minima in the month of January $\left(43 \mu \mathrm{g} \mathrm{m}^{-3}\right)$. The monthly average and temporal variations in $\mathrm{PM}_{2.5}$ and $\mathrm{PM}_{10}$ concentrations are shown in Figs.S2-S3 (see the supplementary information). The highest seasonal average concentration of both $\mathrm{PM}_{2.5}\left(41 \pm 14 \mu \mathrm{g} \mathrm{m}^{-3}\right)$ and $\mathrm{PM}_{10}\left(64 \pm 20 \mu \mathrm{g} \mathrm{m}^{-3}\right)$ were found during summer and minimum seasonal average mass concentration of both $\mathrm{PM}_{2.5}\left(31 \pm 9 \mu \mathrm{g} \mathrm{m}^{-3}\right)$ and $\mathrm{PM}_{10}\left(51 \pm 17 \mu \mathrm{g} \mathrm{m}^{-3}\right)$ were recorded during 
winter. In post-monsoon, the mass concentrations of $\mathrm{PM}_{2.5}\left(40 \pm 11 \mu \mathrm{g} \mathrm{m}^{-3}\right)$ and $\mathrm{PM}_{10}\left(55 \pm 17 \mu \mathrm{g} \mathrm{m}^{-3}\right)$ were recorded higher than the winter and monsoon (Table 1). In the present case, non-significant seasonal variation in mass concentrations of both $\mathrm{PM}_{2.5}$ and $\mathrm{PM}_{10}$ was recorded at Darjeeling (except winter). Sharma et al. (2014b) reported the similar concentration of $\mathrm{PM}_{2.5}$ (at Kullu: $34 \pm 2 \mu \mathrm{g} \mathrm{m}^{-3}$; at Shimla: $32 \pm 3 \mu \mathrm{g} \mathrm{m}^{-3}$ ) at the north-western Himalayan region during winter 2013, whereas Kaushal et al. (2018) recorded the $52 \pm 18 \mu \mathrm{g} \mathrm{m}^{-3}$ of $\mathrm{PM}_{10}$ concentration at Pohara of north-western Himalaya (Himachal Pradesh) during winter 2015. Sharma et al. (2020a) reported the PM 10 concentration as $54 \pm 12 \mu \mathrm{g} \mathrm{m}^{-3}$ and $39 \pm 10 \mu \mathrm{g} \mathrm{m}^{-3}$ during post-monsoon and winter, respectively at Nainital a central Himalaya. Sharma et al. (2020b) also reported the $\mathrm{PM}_{10}$ concentration as $48 \pm 16 \mu \mathrm{g} \mathrm{m}^{-3}$ during winter in Darjeeling. The monthly variation in mass concentration of $\mathrm{PM}_{2.5}$ and $\mathrm{PM}_{10}$ in relation ambient temperature, $\mathrm{RH}$, wind direction and wind speed is depicted in Figs.S1-S2 (see the supplementary information). It has been observed that the prevailing meteorology of the sampling site influenced the seasonal variation in mass concentrations of $\mathrm{PM}_{2.5}$ and $\mathrm{PM}_{10}$ at Darjeeling. However, the higher concentration of pollutants during the summer season at Darjeeling might be due to more influence of tourism activities (Gajananda et al. 2005; Chatterjee et al. 2021) as well as long-range transportation of pollutants at sampling site of the Darjeeling (Rai et al. 2020a).

\subsubsection{Variation of OC, EC and WSOC in $\mathrm{PM}_{2.5}$ and $\mathrm{PM}_{10}$}

Temporal variations in $\mathrm{OC}, \mathrm{EC}$ and WSOC concentrations of $\mathrm{PM}_{2.5}$ and $\mathrm{PM}_{10}$ during study period are shown in Fig.S3 (b-d) (see the supplementary information). The annual average concentrations of OC, EC, WSOC and WIOC of $\mathrm{PM}_{2.5}$ were $3.46 \pm 1.59 \mu \mathrm{g} \mathrm{m}^{-3}, 1.93 \pm 0.93 \mu \mathrm{g} \mathrm{m}^{-3}, 1.88 \pm 1.05 \mu \mathrm{g} \mathrm{m}^{-3}$ and $1.69 \pm 0.85 \mu \mathrm{g} \mathrm{m}^{-3}$, respectively. Whereas the annual average of OC, EC, WSOC and WIOC in $\mathrm{PM}_{10}$ were $5.06 \pm 2.03 \mu \mathrm{g} \mathrm{m}^{-3}, 2.34 \pm 1.18 \mu \mathrm{g} \mathrm{m}^{-3}, 3.55 \pm 1.75 \mu \mathrm{g}$ $\mathrm{m}^{-3}$ and $1.51 \pm 0.92 \mu \mathrm{g} \mathrm{m}^{-3}$, respectively. Figure 2 shows the monthly average of OC, EC and WSOC in $\mathrm{PM}_{2.5}$ and $\mathrm{PM}_{10}$ during study period in Darjeeling. Highest monthly average $\mathrm{OC}$ in $\mathrm{PM}_{2.5}\left(4.76 \mu \mathrm{g} \mathrm{m}^{-3}\right)$ and $\mathrm{PM}_{10}\left(6.30 \mu \mathrm{g} \mathrm{m}^{-3}\right)$ was found in November (post-monsoon), whereas monthly average minima of OC in $\mathrm{PM}_{2.5}\left(2.03 \mu \mathrm{g} \mathrm{m}^{-3}\right)$ and $\mathrm{PM}_{10}$ $\left(3.31 \mu \mathrm{g} \mathrm{m}^{-3}\right.$ ) was found in August (monsoon) and May (summer), respectively. Similar monthly average maxima and minima of EC (in $\mathrm{PM}_{2.5}$ and $\mathrm{PM}_{10}$ ) was recorded in March and August, respectively (Fig. 2). Highest monthly average WSOC concentration in both $\mathrm{PM}_{2.5}\left(2.77 \mu \mathrm{g} \mathrm{m}^{-3}\right)$ and $\mathrm{PM}_{10}\left(5.51 \mu \mathrm{g} \mathrm{m}^{-3}\right)$ was recorded in November (postmonsoon) might be due to the influence of stubble burning in northern states of India (Punjab, Haryana and western Utter Pradesh of IGP). Figure 3 shows the seasonal average OC, EC, WSOC, WIOC, POC, SOC and TCA 
concentrations of $\mathrm{PM}_{2.5}$ and $\mathrm{PM}_{10}$ during winter, summer, monsoon and post-monsoon seasons in Darjeeling. Highest seasonal average $\mathrm{OC}$ concentration of $\mathrm{PM}_{2.5}\left(4.07 \pm 1.55 \mu \mathrm{g} \mathrm{m}^{-3}\right)$ and $\mathrm{PM}_{10}\left(5.69 \pm 2.09 \mu \mathrm{g} \mathrm{m}^{-3}\right)$ was recorded in post-monsoon season and minimum seasonal average concentration of OC in $\mathrm{PM}_{2.5}\left(2.21 \pm 0.86 \mu \mathrm{g} \mathrm{m}^{-3}\right)$ and $\mathrm{PM}_{10}$ $\left(3.62 \pm 0.86 \mu \mathrm{g} \mathrm{m}^{-3}\right)$ was recorded during monsoon (Table 1). Similarly, seasonal average maxima and minima of EC in $\mathrm{PM}_{2.5}$ and $\mathrm{PM}_{10}$ were recorded in summer and monsoon seasons, respectively. Average WSOC in both $\mathrm{PM}_{2.5}$ $\left(2.17 \pm 0.98 \mu \mathrm{g} \mathrm{m}^{-3}\right)$ and $\mathrm{PM}_{10}\left(4.44 \pm 1.55 \mu \mathrm{g} \mathrm{m}^{-3}\right)$ were found highest during post-monsoon season and minimum in monsoon season (Fig. 3).

The annual average concentration of TCA contributes $20.6 \%$ of $\mathrm{PM}_{2.5}\left(7.6 \pm 3.4 \mu \mathrm{g} \mathrm{m}^{-3}\right)$ and $18.6 \%$ of $\mathrm{PM}_{10}$ $\left(10.4 \pm 4.3 \mu \mathrm{g} \mathrm{m}^{-3}\right)$. The highest TCA in $\mathrm{PM}_{2.5}$ and $\mathrm{PM}_{10}$ were recorded in winter $\left(22.7 \%\right.$ of $\mathrm{PM}_{2.5}$ and $22.4 \%$ of $\mathrm{PM}_{10}$ ) season followed by post-monsoon (21.7\% of $\mathrm{PM}_{2.5}$ and 20.3\% of $\left.\mathrm{PM}_{10}\right)$, summer (21.6\% of $\mathrm{PM}_{2.5}$ and $17.6 \%$ of $\left.\mathrm{PM}_{10}\right)$ and monsoon (12.5\% of $\mathrm{PM}_{2.5}$ and $13.4 \%$ of $\left.\mathrm{PM}_{10}\right)$ seasons. The annual average concentration of POC in $\mathrm{PM}_{2.5}$ was recorded to be $2.35 \pm 1.06 \mu \mathrm{g} \mathrm{m}^{-3}$ (66\% of OC), and SOC was $1.19 \pm 0.57 \mu \mathrm{g} \mathrm{m}^{-3}$ ( $34 \%$ of OC). Similarly, the annual average POC concentration in $\mathrm{PM}_{10}$ was recorded as $3.18 \pm 1.13 \mu \mathrm{g} \mathrm{m}^{-3}$ (63\% of OC), whereas, SOC was recorded as $2.05 \pm 0.98 \mu \mathrm{g} \mathrm{m}^{-3}$ (37\% of OC). In $\mathrm{PM}_{2.5}$ the seasonal contribution of POC and SOC were ranging from $55-77 \%$ and $33-45 \%$ of OC, respectively, whereas in $\mathrm{PM}_{10}$ the seasonal contribution of POC and SOC were ranging from 51-73\% and 37-49\% of OC, respectively. Sen et al. (2018) reported the similar OC $\left(7.7 \pm 0.7 \mu \mathrm{g} \mathrm{m}^{-3}\right)$ and EC $\left(3.7 \pm 0.6 \mu \mathrm{g} \mathrm{m}^{-3}\right)$ concentrations in $\mathrm{PM}_{10}$ at Darjeeling and high OC $\left(10.3 \pm 5.6 \mu \mathrm{g} \mathrm{m}^{-3}\right)$ and $\mathrm{EC}\left(5.4 \pm 2.9 \mu \mathrm{g} \mathrm{m}^{-3}\right)$ values in $\mathrm{PM}_{10}$ at Kullu-Mohal (north-western Himalayas) during winter. Whereas, Rai et al. (2020a) observed the low OC $\left(3.7 \pm 1.3 \mu \mathrm{g} \mathrm{m}^{-3}\right)$ and EC $\left(1.3 \pm 0.6 \mu \mathrm{g} \mathrm{m}^{-3}\right)$ in $\mathrm{PM}_{10}$ at Darjeeling. Sharma et al. (2020a) also found the similar OC and EC concentrations in $\mathrm{PM}_{10}$ over Nainital (central Himalayas) during post-monsoon (OC: $4.7 \pm 1.1 \mu \mathrm{g}$ $\mathrm{m}^{-3}$ and EC: $1.1 \pm 0.5 \mu \mathrm{g} \mathrm{m}^{-3}$ ) and winter (OC: $3.2 \pm 1.1 \mu \mathrm{g} \mathrm{m}^{-3}$ and EC: $1.4 \pm 0.6 \mu \mathrm{g} \mathrm{m}^{-3}$ ) seasons.

Figure 2 shows the monthly average OC/EC and WSOC/OC ratios of $\mathrm{PM}_{2.5}$ and $\mathrm{PM}_{10}$ at Darjeeling, whereas seasonal relationship between OC and EC, WSOC and OC of $\mathrm{PM}_{2.5}$ and $\mathrm{PM}_{10}$ are depicted in Figs. S4-S5 (see the supplementary information). The seasonal average OC/EC of $\mathrm{PM}_{2.5}$ was 1.87 (range: 1.40 - 2.81), 1.92 (range: 1.22 -

241 2.82), 1.85 (range: 1.30 - 2.57) and 1.94 (range: 1.05 -2.87) during winter, summer, monsoon and post-monsoon, 242 respectively. The seasonal average WSOC/OC ratio of $\mathrm{PM}_{2.5}$ was computed as $0.50,0.52,0.53$ and 0.54 during winter, summer, monsoon and post-monsoon, respectively. Similarly, the seasonal average OC/EC of $\mathrm{PM}_{10}$ was 
average WSOC/OC of $\mathrm{PM}_{10}$ was $0.71,0.61,0.65$ and 0.79 during winter, summer, monsoon and post-monsoon, respectively. Hegde et al. (2016) also observed a similar (0.51 \pm 0.06 for TSP) WSOC/OC value in Nainital during winter. Due to poor solubility of organics emitted from the combustion of liquid fossil fuels the WSOC/OC values for vehicular emissions are low as compared to biomass burning. In this study, significant positive correlation between OC vs. EC (for $\mathrm{PM}_{2.5}: R^{2}=0.88,0.86,0.63$ and 0.80 at $p<0.05$; for $\mathrm{PM}_{10}: R^{2}=0.77,0.85,0.09$ and 0.74 at $p<0.05$ during winter, summer, monsoon and post-monsoon seasons, respectively) of $\mathrm{PM}_{2.5}$ and $\mathrm{PM}_{10}$ has been observed during all the seasons (except monsoon season for $\mathrm{PM}_{10}$ ) (Figs. S4-S5; in supplementary information), which is indicative of their common sources (Rengarajan et al. 2007; Ram and Sarin 2011). The scatter plots between WSOC and OC (for $\mathrm{PM}_{2.5}: R^{2}=0.63,0.73,0.62$ and 0.83 ; and for $\mathrm{PM}_{10}: R^{2}=0.69,0.91,0.17$ and 0.87 during winter, summer, monsoon and post-monsoon seasons, respectively) of $\mathrm{PM}_{2.5}$ and $\mathrm{PM}_{10}$ (except monsoon season for $\mathrm{PM}_{10}$ ) shows significant positive correlation suggesting that both $\mathrm{OC}$ and $\mathrm{EC}$ are obtained from the same primary emission source or by similar secondary processes (Figs. S4-S5; in supplementary information). The nonsignificant positive correlation of $\mathrm{K}$ (a tracer of biomass) with $\mathrm{Ca}$, $\mathrm{Mg}$, WSOC of $\mathrm{PM}_{2.5}$ and significant positive correlation of $\mathrm{K}$ with $\mathrm{Ca}, \mathrm{Mg}$, WSOC of $\mathrm{PM}_{10}$ during all the seasons (except post-monsoon season for $\mathrm{PM}_{2.5}$ ) demonstrate the abundance of soil/road dust contributed by soluble organic sources to $\mathrm{PM}_{2.5}$ and $\mathrm{PM}_{10}$ at study site (Tables: S1-S8; in supplementary information). I may also be considered that the soil suspension, fuel combustion (Urban et al. 2012), and formation of secondary water soluble organic aerosols (Lim et al. 2010) might be the some other sources of WSOC in the sampling site of Darjeeling.

\subsubsection{Major and trace elements in $P M_{2.5}$ and $P M_{10}$}

During the sampling 17 common elements (Al, Fe, Ti, Cu, Zn, Mn, Cr, Ni, Mo, Cl, P, S, K, Zr, Pb, Na, Mg, Ca, and $\mathrm{B})$ were extracted in $\mathrm{PM}_{2.5}$ and $\mathrm{PM}_{10}\left(\mathrm{Cu}\right.$ and $\mathrm{Pb}$ in $\mathrm{PM}_{10}$ but traced in few $\mathrm{PM}_{2.5}$ samples also) using X-RF technique of sampling site (Table 1). In $\mathrm{PM}_{2.5}$ samples, $\mathrm{Na}$ has observed highest annual average concentration $\left(1.014 \pm 0.392 \mu \mathrm{g} \mathrm{m}^{-3}\right)$ followed by $\mathrm{Ca}\left(0.918 \pm 0.813 \mu \mathrm{g} \mathrm{m}^{-3}\right), \mathrm{S}\left(0.667 \pm 0.404 \mu \mathrm{g} \mathrm{m}^{-3}\right), \mathrm{Fe}\left(0.502 \pm 0.195 \mu \mathrm{g} \mathrm{m}^{-3}\right)$, $\mathrm{K}\left(0.388 \pm 0.224 \mu \mathrm{g} \mathrm{m}^{-3}\right)$, and so on with higher loading in summer season (Table 1). Whereas in case of $\mathrm{PM}_{10}, \mathrm{~S}$ has recorded highest annual average concentration $\left(1.260 \pm 0.744 \mu \mathrm{g} \mathrm{m}^{-3}\right)$ followed by $\mathrm{Ca}\left(0.985 \pm 0.299 \mu \mathrm{g} \mathrm{m}^{-3}\right)$, $\mathrm{Al}\left(0.922 \pm 0.446 \mu \mathrm{g} \mathrm{m}^{-3}\right), \mathrm{K}\left(0.650 \pm 0.376 \mu \mathrm{g} \mathrm{m}^{-3}\right), \mathrm{Fe}\left(0.635 \pm 0.266 \mu \mathrm{g} \mathrm{m}^{-3}\right), \mathrm{Na}\left(0.607 \pm 0.396 \mu \mathrm{g} \mathrm{m}^{-3}\right)$, and so on. The annual average concentrations of elements in $\mathrm{PM}_{2.5}$ and $\mathrm{PM}_{10}$ are $5.71 \pm 3.67 \mu \mathrm{g} \mathrm{m}^{-3}$ (accounted for $15 \%$ of 
$\mathrm{PM}_{2.5}$ ) and $6.44 \pm 3.58 \mu \mathrm{g} \mathrm{m}^{-3}$ (accounted for $12 \%$ of $\mathrm{PM}_{10}$ ), respectively. The monthly average concentrations of elements of $\mathrm{PM}_{2.5}$ and $\mathrm{PM}_{10}$ are shown in Fig. S6 (see the supplementary information). Higher average concentrations of elements are recorded during summer (21\% of $\mathrm{PM}_{2.5}$ and $12 \%$ of $\mathrm{PM}_{10}$ ) followed by winter (16.5\% of $\mathrm{PM}_{2.5}$ and 11.7 of $\mathrm{PM}_{10}$ ), post-monsoon (11.6\% of $\mathrm{PM}_{2.5}$ and $11 \%$ of $\mathrm{PM}_{10}$ ) and monsoon (9\% of $\mathrm{PM}_{2.5}$ and 13\% of $\mathrm{PM}_{10}$ ) seasons (Fig. 4). During winter 2013 land campaign, Sharma et al. (2014b) found the Na, Mg, Ca, $\mathrm{Al}, \mathrm{P}, \mathrm{S}, \mathrm{Si}, \mathrm{Cl}, \mathrm{K}, \mathrm{Ti}, \mathrm{Sr}, \mathrm{Zr}, \mathrm{Pb}, \mathrm{Sb}, \mathrm{Ag}, \mathrm{Cs}, \mathrm{Hg}, \mathrm{Mn}, \mathrm{Fe}$ and $\mathrm{Zn}$ in $\mathrm{PM}_{2.5}$ (which had accounted for $22 \%$ of $\mathrm{PM}_{2.5}$ ) over the north-western Himalaya. Sharma et al. (2020a) also reported the elements contribution to $\mathrm{PM}_{10}$ as $16 \%$ and 13\% during post-monsoon and winter seasons, respectively at central Himalaya (Nainital). The similar contribution of elements to the $\mathrm{PM}_{10}$ over the Himalayan region and other high altitude regions are discussed in our earlier publication (Sharma et al. 2020b).

Figure 5 represents the seasonal enrichment factors (EFs) of the elements ( $\mathrm{Al}, \mathrm{Fe}, \mathrm{Ti}, \mathrm{Cu}, \mathrm{Zn}, \mathrm{Mn}, \mathrm{Cr}, \mathrm{Ni}, \mathrm{Mo}$, $\mathrm{Cl}, \mathrm{P}, \mathrm{S}, \mathrm{K}, \mathrm{Zr}, \mathrm{Pb}, \mathrm{Na}, \mathrm{Mg}, \mathrm{Ca}$, and $\mathrm{B}$ ) available in $\mathrm{PM}_{2.5}$ and $\mathrm{PM}_{10}$ samples. $\mathrm{Al}, \mathrm{Fe}, \mathrm{Ti}, \mathrm{K}, \mathrm{Mg}$, and $\mathrm{Ca}$ in both $\mathrm{PM}_{2.5}$ and $\mathrm{PM}_{10}$ have recorded low EFs $(<5)$ for all the seasons, which indicate that, elements mostly arrived from crustal/soil sources. The element like $\mathrm{Cu}, \mathrm{Zn}, \mathrm{Ni}, \mathrm{Pb}, \mathrm{Cr}$, Mo and B have higher EFs (>10) in both $\mathrm{PM}_{2.5}$ and $\mathrm{PM}_{10}$ and therefore are likely of anthropogenic origin. The higher the $\mathrm{EF}$ of $\mathrm{Cr}, \mathrm{Ni}, \mathrm{Pb}$ and $\mathrm{Zn}$ of $\mathrm{PM}$ were also attributed to industrial emission (IE) sources. Generally $\mathrm{Cu}, \mathrm{Mn}, \mathrm{Zn}, \mathrm{Ni}, \mathrm{Cd}, \mathrm{Fe}, \mathrm{Mo}, \mathrm{S}$ and $\mathrm{Cr}$ use as a marker for IE in India (Shridhar et al. 2010).

The annual and seasonal statistical summary of elements recorded in $\mathrm{PM}_{2.5}$ and $\mathrm{PM}_{10}$ samples is tabulated in Table 1. The possible sources of trace metals present in a fine and coarse fraction of particulates can be primarily crustal/mineral dust. In this study, $\mathrm{Al}$, is significantly positive correlated with $\mathrm{Fe}, \mathrm{Ca}, \mathrm{Mg}$ and $\mathrm{Ti}$ (as well as with $\mathrm{PM}_{10}$ ) and the average $\mathrm{Fe} / \mathrm{Al}$ ratio is 0.69 (winter: 0.76; summer: 0.74; monsoon: 0.45 and post-monsoon: 0.79 ), which indicates the dominant source of mineral dust. Similarly, $\mathrm{Ca} / \mathrm{Al}$ ratio (1.07) indicates that PM over the eastern Himalayan region is rich in Ca mineral as compared to average continental crust. Similar results were also observed in case of elements extracted in $\mathrm{PM}_{2.5}$ over the eastern Himalaya. Sarin et al. (1979) had reported that the $\mathrm{Fe} / \mathrm{Al}$ ratio in north Indian plains ranged from 0.55 to 0.63 . Kumar and Sarin (2009) reported Fe/Al ratio as 0.59 for $\mathrm{PM}_{2.5-10}$ at a remote high altitude sampling site (Manora Peak) of western India. McLennan, (2001) recorded the average Ca/Al ratio as 1.07 in $\mathrm{PM}_{10}$ whereas, the corresponding ratio in the upper continental crust is 0.38 . Sharma et al. (2020a) also reported $\mathrm{Ca} / \mathrm{Al}$ ratio as 1.52 and 1.19 in $\mathrm{PM}_{10}$ during post-monsoon and winter seasons, respectively at central 
Himalayas (Nainital), whereas Kumar and Sarin (2009) had recorded the $\mathrm{Ca} / \mathrm{Al}$ ratio as 0.73 in $\mathrm{PM}_{2.5}$ and 1.74 in $\mathrm{PM}_{10}$ at Manora Peak, a high altitude site of the western India. The significant positive correlation of $\mathrm{Al}$ with $\mathrm{Fe}, \mathrm{Ca}$, $\mathrm{Mg}$ and Ti of coarse and fine (except few in $\mathrm{PM}_{2.5}$ ) fractions of PM during all the seasons are also indicated the abundance of mineral dust at the sampling site of Darjeeling (Table S1-S8; in supplementary information).

\subsection{Possible sources and source regions}

\subsubsection{Possible sources of $\mathbf{P M}_{2.5}$ and $\mathrm{PM}_{10}$}

PCA has been performed with chemical species of $20 \mathrm{PM}_{2.5}$ and $22 \mathrm{PM}_{10}(\mathrm{OC}, \mathrm{EC}, \mathrm{WSOC}, \mathrm{Na}, \mathrm{Ca}, \mathrm{Mg}, \mathrm{Al}, \mathrm{Fe}$, Ti, K, Cl, P, S, Cr, Ni, Cu, Zn, Mn, Mo, Zr, $\mathrm{Pb}$ and B) to identify the factor loading to $\mathrm{PM}_{2.5}$ and $\mathrm{PM}_{10}$. The factor profiles (a yearlong data) of the possible sources of $\mathrm{PM}_{2.5}$ and $\mathrm{PM}_{10}$ extracted by PCA are summarized in Table 2. On the basis of the factor loading PCA resolved the four common sources [biomass burning + fossil fuel combustion (BB+FFC), crustal/soil dust (SD), vehicular emissions (VE) and industrial emissions (IE)] of $\mathrm{PM}_{2.5}$ and $\mathrm{PM}_{10}$ at Darjeeling.

Factor 1: The first factor of $\mathrm{PM}_{2.5}$ represents the $\mathrm{BB}+\mathrm{FFC}$, characterized (38.3\% of the variance) by highly loaded with OC, EC, WSOC, $\mathrm{K}, \mathrm{Cl}$ and S. $\mathrm{K}^{+}$and Levoglucoson are considered BB (cow dung, crop residue, fuel wood, and wildfires, etc.) marker, whereas presence of $\mathrm{Cl}$ in the factor reveals the wood and coal burning (Pant and Harrison, 2012). WSOC/OC and OC/EC mass ratios also evidence the BB+FFC as a one of the sources of $\mathrm{PM}_{2.5}$ at the observational site of Darjeeling (Sharma et al. 2020b; Chatterjee et al. 2021). The first factor of $\mathrm{PM}_{10}$ represented by high loading (36.7\% of the variance) of crustal elements like, $\mathrm{Al}, \mathrm{Ti}, \mathrm{Fe}, \mathrm{Ca}, \mathrm{Mg}, \mathrm{K}$ and $\mathrm{Na}$ which inferred the source as crustal/soil/road dust (Begam et al. 2011; Sharma et al. 2014a; Jain et al. 2020b). The abundance of these elements at the study site as crustal origin is also confirmed by EFs (Fig. 5) as well as positive correlations of Al with $\mathrm{Ca}, \mathrm{Mg}$ and $\mathrm{Ti}$ (Table S1-S8).

Factor 2: This factor of $\mathrm{PM}_{2.5}$ was resolved as crustal/soil dust by high loading of $\mathrm{Al}, \mathrm{Ti}, \mathrm{Fe}, \mathrm{Ca}, \mathrm{Mg}, \mathrm{K}$ and $\mathrm{Na}$ (17.6\% of the variance of factor loading) (Table 2). The EFs of these elements are also suggesting the crustal origin the elements at sampling site (Fig. 5) as well as the positive correlations of $\mathrm{Al}$ with $\mathrm{Ca}, \mathrm{Mg}$ and $\mathrm{Ti}$. Whereas second factor of $\mathrm{PM}_{10}$ represented by BB+FFC with high loadings of OC, EC, WSOC, K, Cl and S (Begam et al. 2011; Pant and Harrison 2012). WSOC/OC and OC/EC ratios are also suggesting the influence of BB+FFC as a source of $\mathrm{PM}_{10}$ at Darjeeling (Sharma et al. 2020b; Chatterjee et al. 2021). 
Factor 3: The third factor of both $\mathrm{PM}_{2.5}$ and $\mathrm{PM}_{10}$ constitutes the vehicular emissions (VE) with the dominant presence of EC, OC, $\mathrm{Zn}, \mathrm{Mn}, \mathrm{Zr}$ and $\mathrm{B}$, indicates the emission derived from road side vehicles (Pant and Harrison, 2012; Jain et al. 2020b). Since, EC and OC are majorily emitted from the combustion sources, so these components are considered as important tracers for VE globally (Yin et al. 2010; Begam et al. 2011). Zn and Mn are used as marker of brake and tire wear, two stroke engine emissions ( $\mathrm{Zn}$ as fuel additive), heavy duty diesel truck emission (Mn as fuel additive) (Kothai et al. 2008; Sharma et al. 2014a). VE is inferred to be one of the major sources of aerosols (Sharma et al. 2020b) at in urban sites of Himalayan region may due to the great influence of tourism activities (Gajananda et al. 2005; Chatterjee et al. 2021).

Factor 4: The fourth source of both $\mathrm{PM}_{2.5}$ and $\mathrm{PM}_{10}$ is characterized as industrial emissions (IE) considering to the higher loading of $\mathrm{Cu}, \mathrm{Zn}, \mathrm{Ni}, \mathrm{Cr}$ and $\mathrm{Mo}$ in aerosol samples (Table 2). These metals $(\mathrm{Cu}, \mathrm{Zn}, \mathrm{Ni}, \mathrm{Cr}$ and $\mathrm{Mo}$ ) might be originated from the small to medial scale industries, metal processing industries and industrial effluents (Gupta et al. 2007; Jain et al. 2019). Sharma et al. (2020b) also reported the solid waste + IE a source of PM10 in Darjeeling with these marker elements.

\subsubsection{Air mass backward trajectory}

To investigate the transport pathway of fine $\left(\mathrm{PM}_{2.5}\right)$ and coarse fractions $\left(\mathrm{PM}_{10}\right)$ of aerosols at the observational site of Darjeeling, 5-days air-mass back trajectory was computed using the HYSPLIT model (Draxeler and Ralph. 2003) at an altitude of 100m, $500 \mathrm{~m}$ and 100m AGL for all the sampling day (Fig.6). In the present case, air parcels approaching to sampling site of Darjeeling is mainly from Bhutan, Nepal, China, Arunachal Pradesh, IGP (Punjab, Haryana, Uttar Pradesh, Bihar and West Bengal) and surrounding regions during all the seasons. During monsoon season, air mass also approaching to sampling site from Bay of Bengal. Chatterjee et al. (2021) reported the similar air parcels towards the Darjeeling during summer and winter season (Sharma et al. 2020b).

\section{Conclusions}

In this study seasonal variation in carbonaceous aerosols and elements in fine and coarse fractions of aerosol $\left(\mathrm{PM}_{2.5}\right.$ and $\left.\mathrm{PM}_{10}\right)$ were estimated to explore the prominent sources of $\mathrm{PM}_{2.5}$ and $\mathrm{PM}_{10}$ in the high altitude of eastern Himalaya during August 2018 - July 2019. The average $\mathrm{PM}_{2.5}$ and $\mathrm{PM}_{10}$ concentrations were recorded as $37 \pm 12 \mu \mathrm{g}$ $\mathrm{m}^{-3}$ and $58 \pm 18 \mu \mathrm{g} \mathrm{m}^{-3}$, respectively during the study. The annual total carbonaceous aerosols in $\mathrm{PM}_{2.5}$ and $\mathrm{PM}_{10}$ were 
accounted for $20.6 \%$ of $\mathrm{PM}_{2.5}$ and $18.6 \%$ of $\mathrm{PM}_{10}$, respectively (along with season variation). The concentrations of elements present in $\mathrm{PM}_{2.5}$ and $\mathrm{PM}_{10}$ were accounted for $15 \%$ and $12 \%$, respectively. During all the seasons, significant positive linear relationship between OC and EC; and OC and WSOC (as well as OC/EC and WSOC/OC) indicate the common sources $(\mathrm{BB}+\mathrm{FFC})$ of both $\mathrm{PM}_{2.5}$ and $\mathrm{PM}_{10}$. EFs analysis the elements present in $\mathrm{PM}$ indicates the abundance of mineral dust at the eastern Himalaya. PCA resolved the four common sources $[(\mathrm{BB}+\mathrm{FFC})$, crustal/SD, (VE) and (IE)] of $\mathrm{PM}_{2.5}$ and $\mathrm{PM}_{10}$ at Darjeeling. 5 days HYSPLIT back trajectory air parcels indicate that the pollutants approaching to Darjeeling are mainly from Bhutan, Nepal, China, Arunachal Pradesh and IGP region (Punjab, Haryana, Uttar Pradesh, Bihar and West Bengal) during all the seasons as well as the Bay of Bengal (mainly in monsoon season).

\section{Acknowledgement:}

The authors are thankful to the Director, CSIR-NPL and Head, Environmental Sciences and Biomedical Division (ES\&BMD), CSIR-NPL for their encouragement and support. Authors are also thankful to Mr. Bivek Gurung and Mrs. Yashodhara Yadav, Bose Institute, Darjeeling for PM sampling and providing the relevant data-sets. Authors thankfully acknowledge the NOAA Air Resources Laboratory for download the air mass trajectories

372 (http://www.arl.noaa.gov/ready/hysplit4.html).

\section{Funding:}

375 The authors are thankfully acknowledged the Department of Science and Technology, Ministry of Science and 376 Technology (Government of India), New Delhi-110016, India for providing financial support for this study 377 (DST/CCP/Aerosol/88/2017). Authors' contributions: Conception and design of the study were planned by SKS; Data collection and analysis were performed by NV, NC, AR, DS, SM and AG; the first draft was written by SKS. Data interpretation was carried out by SKS, AC, TKM and NV. All the authors read and approved the final manuscript. reasonable request. 
Compliance with ethical standards

387 Competing interests: The authors declare that they have no conflict of interest.

388 Ethical approval: Not applicable.

389 Consent to participate: Not applicable.

390 Consent to publish: Not applicable.

391

392

References

393

Adak A, Chatterjee A, Singh A K, Sarkar C, Ghosh S, Raha S (2014) Atmospheric fine mode particulates at eastern Himalaya, India: role of meteorology, long-range transport, and local anthropogenic sources. Aerosol Air Qual Res 14(1): 440-450

Amato F, Alastuey A, Karanasiou A, Lucarelli F, Nava S, Calzolai G, Severi M, Becagli S, Vorne LG, Colombi C, Alves C, Custódio D, Nunes T, Cerqueira M, Pio C, Eleftheriadis K, Diapouli E, Reche C, Minguillón MC, Manousakas MI, Maggos T, Vratolis S, Harrison RM, Querol X (2016) IRUSE-LIFE. Atmos Chem Phys 16:3289-309

Begam G R, Vachaspati CV, AhammedYN, Kumar KR, Reddy RR, Sharma SK, Saxena M, Mandal TK (2017) Seasonal characteristics of water soluble inorganic ions and carbonaceous aerosols in total suspended particulate matter at a rural semi-arid site, Kadapa (India). Environ Sci Poll Res 24(2): 1719-1734

Begum B A, Hossain A, Saroar G, Biswas S K, Nasiruddin M, Nahar N, Chowdury Z, Hopke P K (2011) Sources of carbonaceous materials in the airborne particulate matter of Dhaka. Asian J Atmos Environ 5(4): 237-246

Behera SN, Sharma M (2010) Investigating the potential role of ammonia in ion chemistry of fine particulate matter formation for an urban environment. Sci Total Environ 408(17): 3569-3575

Belis C, Karagulian F, Larsen B, Hopke P (2013) Critical review and meta-analysis of ambient particulate matter source apportionment using receptor models in Europe. Atmos Environ 69: 94-108

Bond TC, Doherty SJ, Fahey DW, Forster PM, Berntsen T, DeAngelo BJ, Flanner MG, Ghan S, Kärcher B, Koch D, Kinne S (2013) Bounding the role of black carbon in the climate system: A scientific assessment. J Geophy Res 118(11):5380-552 
412 Cao J, Lee S, Ho K, Fung K, Chow JC, Watson JG (2006) Characterization of roadside fine particulate carbon and its eight fractions in Hong Kong. Aerosol Air Qual Res 6 (2): 106-122

414 Castro LM, Pio CA, Harrison RM, Smith DJT (1999) Carbonaceous aerosol in urban and rural European atmospheres: estimation of secondary organic carbon concentrations. Atmos Environ 33: 2771-2781

Chatterjee A, Adak A, Singh, A K, Srivastava M K, Ghosh S K, Tiwari S, Devara PCS, Raha S (2010) Aerosol chemistry over a high-altitude station at the north-eastern Himalayas, India. PloS one 5(6):11122

Chatterjee A, Mukherjee S, Dutta M, Ghosh A, Ghosh SK, Roy A (2021) High rise in carbonaceous aerosols under

very low anthropogenic emissions over eastern Himalaya, India: Impact of lockdown for COVID-19 outbreak. Atmos Environ 244:117947.

Chow J C, Watson JG, Chen L W A, Arnott W P, Moosmuller H (2004) Equivalence of elemental carbon by thermal/optical reflectance and transmittance with different temperature protocols. Environ Sci Technol 38: 4414-4422

Draxler RR, Rolph GD (2003) HYSPLIT (HYbrid Single-particle Lagrangian Integrated Trajectory) Model. Access via NOAA ARL READY website. NOAA Air Resources Laboratory, Silver Spring. http://www.arl.noaa.gov/ready/hysplit4.html

Gajananda K, Kuniyal JC, Momin GA, Rao PSP, Safai PD, Tiwari S, Ali K (2005) Trend of atmospheric aerosols over the north northwestern Himalayan region, India. Atmos Environ 39: 4817-4825

Gupta AK, Karar K, Srivastava A (2007) Chemical mass balance source apportionment of PM 10 and TSP in residential and industrial sites of an urban region of Kolkata, India. J Hazardous Materials 142:279-287

Gupta S, Gadi R, Sharma SK, Mandal TK (2018) Characterization and source apportionment of organic compounds in $\mathrm{PM}_{10}$ using PCA and PMF at a traffic hotspot of Delhi. Sustain Cities Soc 39: 52-67

Hansen J M, Sato R, Rued L, Nazarenko A, Lacis GA, Schmidt G, Russell I, Aleinov M, Bauer S, Bauer N, Bell B, Cairns V, Canuto M, Chandler Y, Cheng A, Del Genio G, Faluvegi E, Fleming A, Friend T, Hall C, Jackman M, Kelley NY, Kiang D, Koch J, Lean J, Lerner K, Lo S, Menon RL, Miller P, Minnis T, Novakov V, Oinas JP, Perlwitz J, Perlwitz D, Rind A, Romanou D, Shindell P, Stone S, Sun N, Tausnev D, Thresher B, Wielicki T, Wong M Y, Zhang X (2005) Efficacy of climate forcings. J Geophys Res 110, D18104 
Hegde P, Kawamura K, Joshi H, Naja M (2016) Organic and inorganic components of aerosols over the central Himalayas: winter and summer variations in stable carbon and nitrogen isotopic composition. Environ Sci Poll Res 23:6102-6118

Jacobson MZ (2002) Control of fossil fuel particulate black carbon and organic matter, possibly the most effective method of slowing global warming. J Geophys Res 107(19): 4410

Jain S, Sharma S K, Vijayan N, Mandal TK (2020) Seasonal characteristics of aerosols $\left(\mathrm{PM}_{2.5}\right.$ and $\left.\mathrm{PM}_{10}\right)$ and their source apportionment using PMF: A four year study over Delhi, India. Environ Poll 262: 114337

Jain S, Sharma SK, Choudhary N, Masiwal R, Saxena M, Sharma A, Mandal TK, Gupta A, Gupta NC, Sharma C (2017) Chemical characteristics and source apportionment of PM$_{2.5}$ using PCA/APCS, UNMIX, and PMF at an urban site of Delhi, India. Environ Sci Poll Res 24(17):14637-14656

Jain S, Sharma SK, Vijayan N, Mandal TK (2020a) Investigating the seasonal variability in source contribution to $\mathrm{PM}_{2.5}$ and $\mathrm{PM}_{10}$ using different receptor models during 2013-2016 in Delhi, India. Environ Sci Poll Res https://doi.org/10.1007/s11356-020-10645-y

Kanakidou M, Seinfeld JH, Pandis SN, Barnes I, Dentener FJ, Facchini MC, Dingenen RV, Ervens B, Nenes ANCJSE, Nielsen CJ, Swietlicki E (2005) Organic aerosol and global climate modelling: a review. Atmos Chem Phy 5(4):1053-1123

Kaushal D, Kumar A, Yadav S, Tandon A, Attri AK (2018) Wintertime carbonaceous aerosols over Dhauladhar region of North-Western Himalayas. Environ Sci Poll Res 25:8044-8056

Kothai P, Saradhi IV, Prathibha P, Hopke PK, Pandit GG, Puranik VD (2008) Source apportionment of coarse and fine particulate matter at Navi Mumbai,India. Aerosol Air Qual Res 8(4): 423-436

Kumar A, Attri A K (2016) Biomass combustion a dominant source of carbonaceous aerosols in the ambient environment of western Himalayas. Aerosol Air Qual Res 16(3): 519-529

Kumar A, Sarin MM (2009) Mineral aerosols from western India: temporal variability of course and fine atmospheric dust and elemental characteristics. Atmos Environ 43:4005-4013

Lighty J S, Veranth JM, Sarofim AF (2000) Combustion aerosols: factors governing their size and composition implications to human health. J Air Waste Manag Assoc 50 (9):1565-1618

Lim HJ, Turpin B J (2002) Origins of primary and secondary organic aerosol in Atlanta: Results of time-resolved measurements during the Atlanta supersite experiment. Environ Sci Technol 36: 4489-4496 
467

468

469

470

471

472

473

474

475

476

477

478

479

480

481

482

483

484

485

486

487

488

489

490

491

492

493

494

Lim Y B, Tan Y, Perri M J, Seitzinger S P, Turpin B J (2010) Aqueous chemistry and its role in secondary organic aerosol (SOA) formation. Atmos Chem Phys Discussions 10(6)

Mandal P, Sarkar R, Mandal A, Saud T (2014). Seasonal variation and sources of aerosol pollution in Delhi, India. Environ Chem Lett 12(4): 529-534

McLennan S (2001) Relationship between the trace element composition of sedimentary rocks and upper continental crust. Geochem Geophys Geosyst 2:1021, doi: 10.1029/2000/ GC 000109

Morawska L, Zhang JJ (2002) Combustion sources of particles. Health relevance and source signatures. Chemosphere 49: 1045-1058

Pant P, Harrison R M (2012) Critical review of receptor modeling for particulate matter: a case study of India. Atmos Environ 49: 1-12

Pope C A, Ezzati M, Dockery DW (2009) Fine-particulate air pollution and life expectancy in the United States. New England Journal of Medicine 360(4): 376-386

Rai A, Mukherjee S, Chatterjee A, Choudhary N, Kotnala G, Mandal TK, Sharma SK (2020a) Seasonal variation of OC, EC and WSOC of PM10 and their CWT analysis over the eastern Himalaya. Aerosol Sci Eng 4:26-40

Rai P, Furger M, El Haddad I, Kumar V, Wang L, Singh A, Dixit K, Bhattu D, Petit JE, Ganguly D, Rastogi N (2020b) Real-time measurement and source apportionment of elements in Delhi's atmosphere. Sci Total Environ 742:140332

Ram K, Sarin M, Hegde P (2008) Atmospheric abundances of primary and secondary carbonaceous species at two high altitude sites in India: sources and temporal variability. Atmos Environ 42(28): 6785-6796

Ram K, Sarin MM (2011) Day-night variability of EC, OC, WSOC and inorganic ions in urban environment of Indo-Gangetic Plain: Implications to secondary aerosol formation. Atmos Environ 45:460-468

Ramana MV, Ramanathan V, Feng Y, Yoon SC, Kim SW, Carmichael G R, Schauer J J (2010) Warming influenced by the ratio of black carbon to sulphate and the black-carbon source. Nat Geosci 3:542-545

Ramgolam K, Favez O, Cachier H, Gaudichet A, Marano F, Martinon L (2009) Size-partitioning of an urban aerosol to identify particle determinants involved in the pro-inflammatory response induced in airway epithelial cells. Particle and Fibre Toxicology 6(1), doi:10.1186/1743-8977-6-10

Rastogi N, Sarin M M (2009) Quantitative chemical composition and characteristics of aerosols over western India: One-year record of temporal variability. Atmos Environ 43(22-23): 3481-3488 
Rengarajan R, Sarin MM, Sudheer AK (2007) Carbonaceous and inorganic species in atmospheric aerosols during wintertime over urban and high-altitude sites in North India. J Geophy Res 112:D21307

Robinson A L, Donahue N M, Shrivastava M K, Weitkamp E A, Sage A M, Grieshop A P, Pandis S N, (2007) Rethinking organic aerosols: Semivolatile emissions and photochemical aging. Science 315 (5816):12591262

Sarin MM, Borole DV, Krishnaswami S (1979) Geochemistry and geochronology of sediments from the Bay of Bengal and the equatorial Indian Ocean. Proc. Indian Academy of Science 88:131-154

Sarkar C, Chatterjee A, Majumdar D, Roy A, Srivastava A, Ghosh S K, Raha S (2017) How the atmosphere over eastern Himalaya, India is polluted with carbonyl compounds? Temporal variability and identification of sources. Aerosol Air Qual Res 17:2206-2223

Sen A, Karapurkar S G, Saxena M, Shenoy D M, Chaterjee A, Choudhuri A K, Das T, Khan A H, Kuniyal J C, Pal S, Singh D P, Sharma S K, Kotnala R K, Mandal T K (2018) Stable carbon and nitrogen isotopic composition of $\mathrm{PM}_{10}$ over Indo-Gangetic Plains (IGP), adjoining regions, and Indo-Himalayan Range (IHR) during the winter 2014 campaign. Environ Sci Poll Res 25(26): 26279-26296

Sharma S K, Mandal T K, Dey A K, Deb N, Jain S, Saxena M, Pal S, Choudhuri AK, Yadav S (2018a) Carbonaceous and inorganic species in $\mathrm{PM}_{10}$ during wintertime over Giridih, Jharkhand (India). J Atmos Chem 75:219-233

Sharma S K, Mandal T K, Jain S, Saraswati, Sharma A, Saxena M (2016) Source apportionment of $\mathrm{PM}_{2.5}$ in Delhi, India using PMF model. Environ Contam Toxicol 97: 286-293

Sharma S K, Mandal T K, Saxena M, Sharma A, Gautam R (2014a) Source apportionment of PM 10 by using positive matrix factorization at an urban site of Delhi, India. Urban climate 10: 656-670

Sharma S K, Mandal T K, Sharma C, Kuniyal J C, Joshi R, Dhyani P P, Rohtash, Ghayas H, Gupta NC, Sharma P, Saxena M, Sharma A, Arya BC, Kumar A (2014b) Measurements of particulate $\left(\mathrm{PM}_{2.5}\right)$, BC and trace gases over the Northwestern Himalayan region of India. Mapan 29(4): 243-253

Sharma S K, Mandal TK, Sharma A, Saraswati, Jain S (2018b) Seasonal and annual trends of carbonaceous species of $\mathrm{PM}_{10}$ over a megacity Delhi, India during 2010-2017. J Atmos Chem 75: 305-318 
521 Sharma SK, Choudhary N, Kotnala G, Das D, Mukherjee S, Ghosh A, Vijayan N, Rai A, Chatterjee A, Mandal TK

522

523

524

525

526

527

528

529

530

531

532

533

534

535

536

537

538

539

540

541

542

543

544

545

(2020b) Wintertime carbonaceous species and trace metals in $\mathrm{PM}_{10}$ in Darjeeling: a high altitude town in the eastern Himalayas. Urban Climate 34 (4): 100668

Sharma SK, Choudhary N, Srivastava P, Naja M, Vijayan N, Kotnala G, Mandal TK (2020a) Variation of carbonaceous species and trace elements in $\mathrm{PM}_{10}$ at a mountain site in the central Himalayan region of India. J Atmos Chem 77(3): 49-62

Shivani, Gadi R, Sharma S K, Mandal TK (2019) Seasonal variation, source apportionment and source attributed health risk of fine carbonaceous aerosols over National Capital Region, India. Chemosphere. 237:124500

Shridhar V, Khillare P, Agarwal T, Ray S (2010) Metallic species in ambient particulate matter at rural and urban location of Delhi. J Hazard Mater 175: 600-607

Song Y, Zhang Y, Xie S, Zeng L, Zheng M, Salmon LG, Shao M, Slanina S (2006) Source apportionment of PM 2.5 in Beijing by positive matrix factorization. Atmos Environ 40 (1): 526-1537

Srinivas B, Sarin M M (2014) $\mathrm{PM}_{2.5}$, EC, and OC in an atmospheric outflow from the Indo-Gangetic Plain: temporal variability and aerosol organic carbon-to-organic mass conversion factor. Sci Total Environ 487:196-205

Taylor SR, McLennan, SM (1995) The geochemical evolution of the continental crust. Review of Geophysics 33(2): $241-265$

Urban NB, Slifstein M, Thompson JL, Xu X, Girgis RR, Raheja S, Haney M, Abi-Dargham A (2012) Dopamine release in chronic cannabis users: a [11c] raclopride positron emission tomography study. Biological psychiatry 71(8): 677-683

Viana M, Kuhlbusch T A J, Querol X, Alastuey A, Harrison R M, Hopke P K, Winiwarter W, Vallius M (2008) Source apportionment of particulate matter in Europe: a review of methods and results. J Aerosol Sci 39: 827-849

Yin J, Harrison RM, Chen Q, Rutter A, Schauer J J (2010) Source apportionment of fine particles at urban background and rural sites in the UK atmosphere. Atmos Environ 44(6): 841-851 


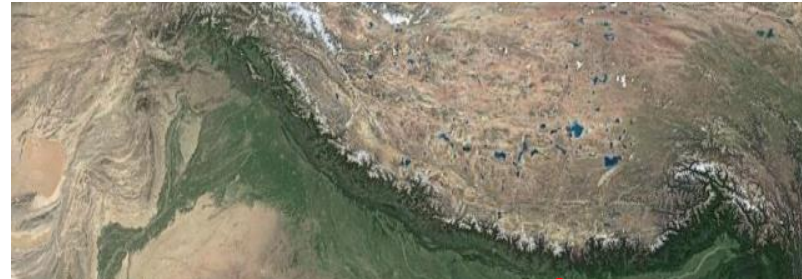

553

554

555

556

557

558

559

560

561

562

563

564

565

566

567

568

569

\section{Darjeeling}

Fig. 1 Map of the observational site (Source: Google maps).

Mahakal Temple :
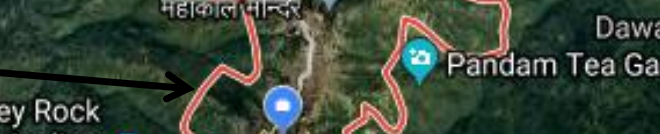

rjeeling o

बारवतिया

क गार्डन... 4 (3)

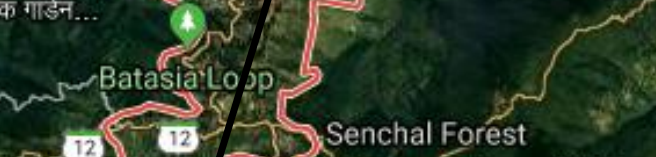

12 12 Senchal Forest
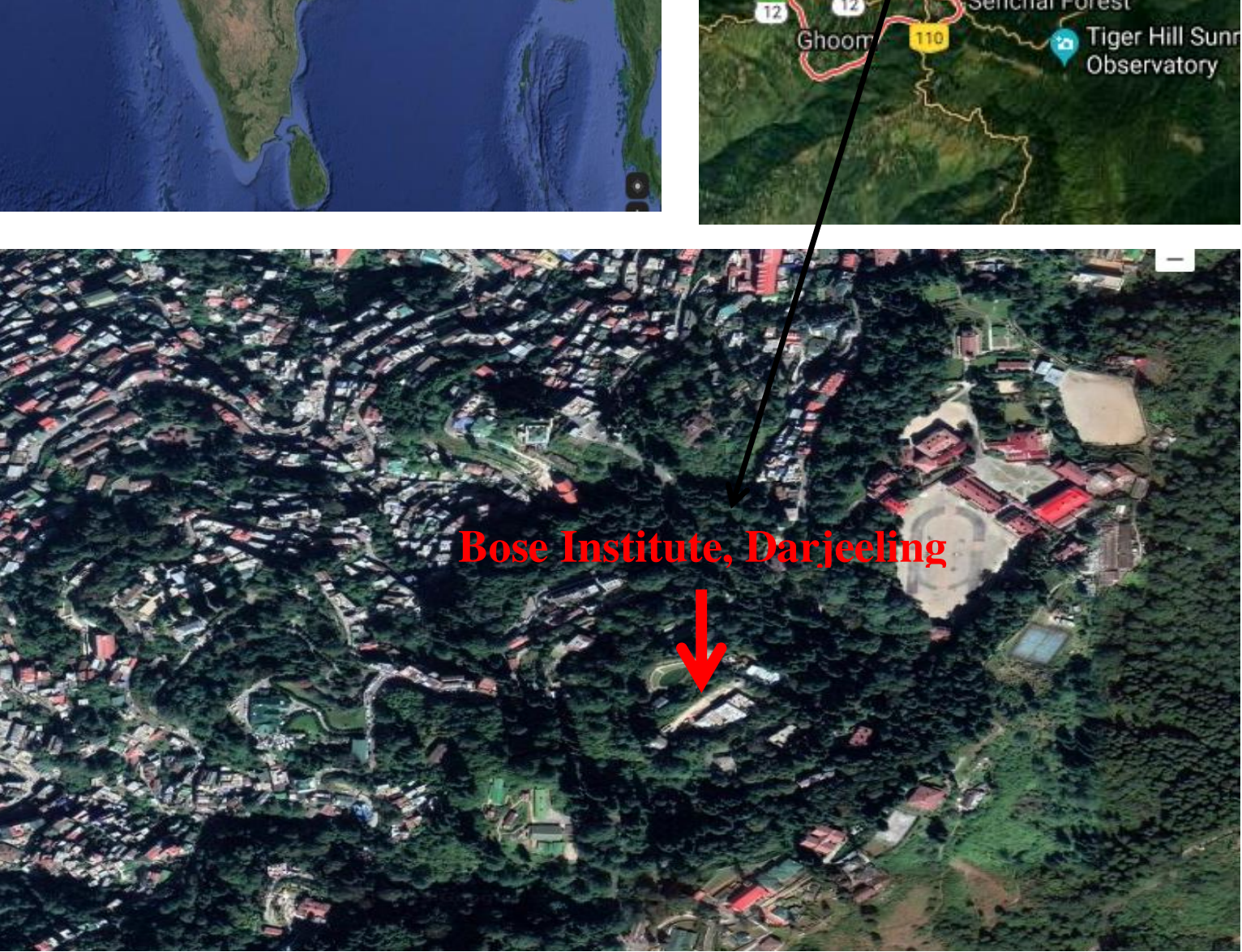


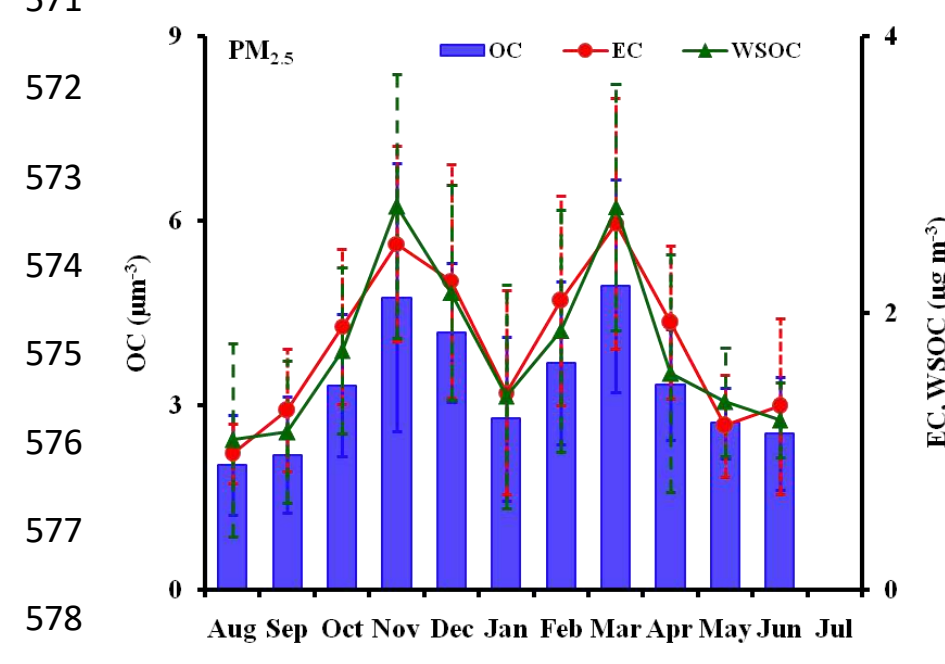

579

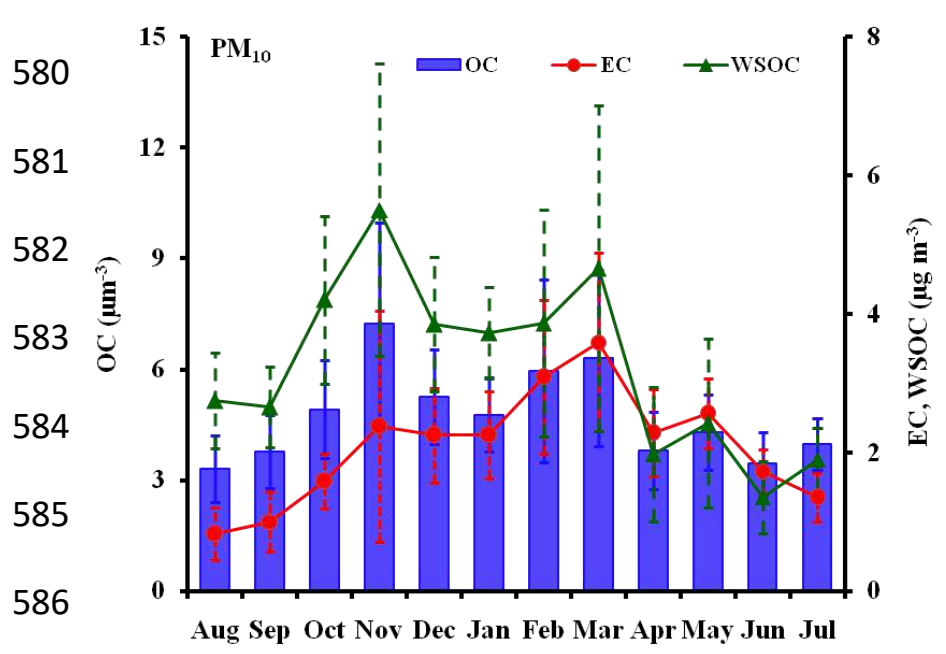

587

588

589 Darjeeling.

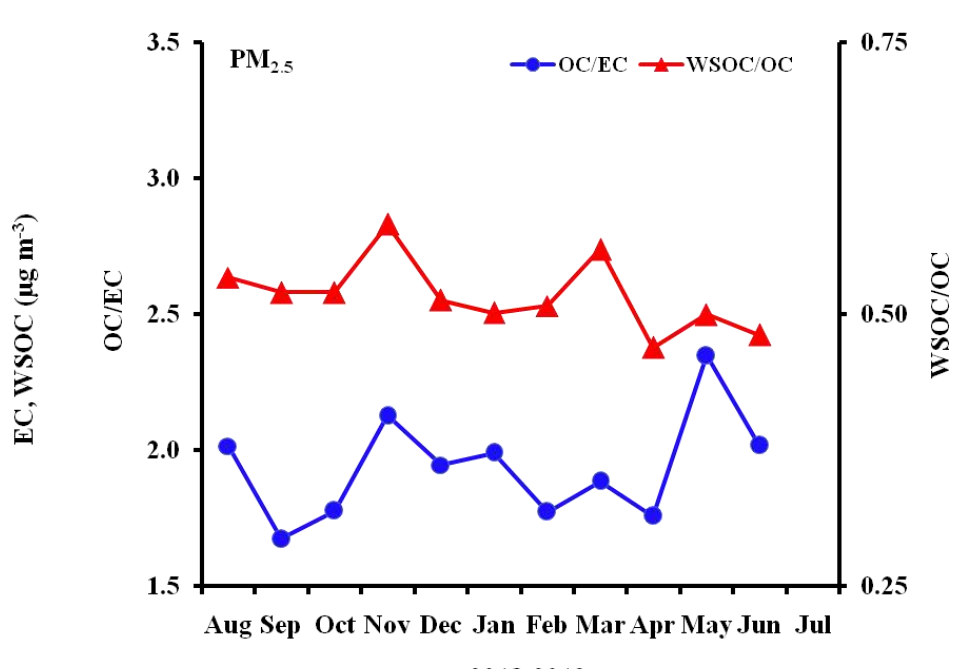

2018-2019

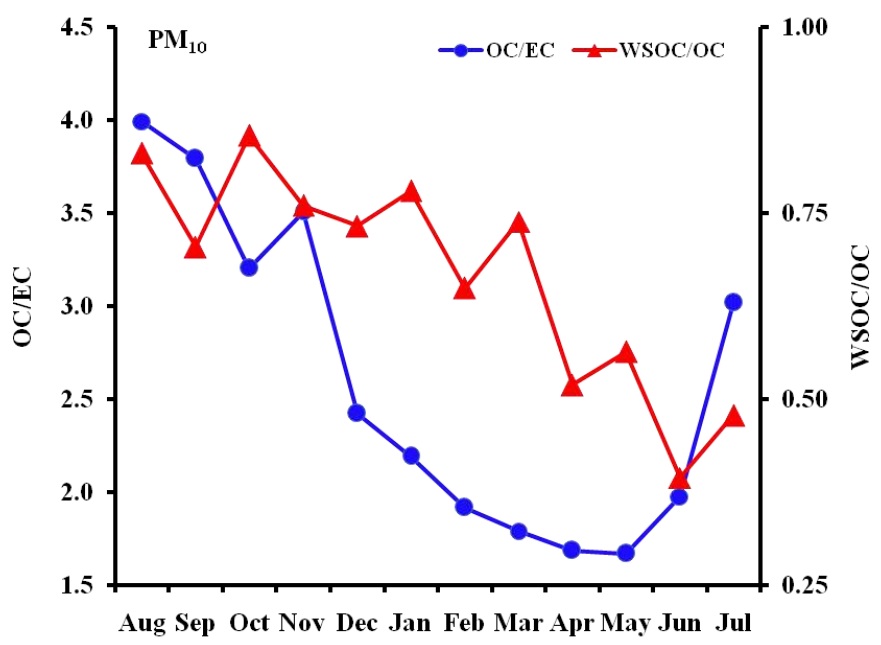

2018-2019

Fig. 2: Monthly average concentrations of $\mathrm{OC}, \mathrm{EC}$ and WSOC and their mass ratios of $\mathrm{PM}_{2.5}$ and $\mathrm{PM}_{10}$ at 


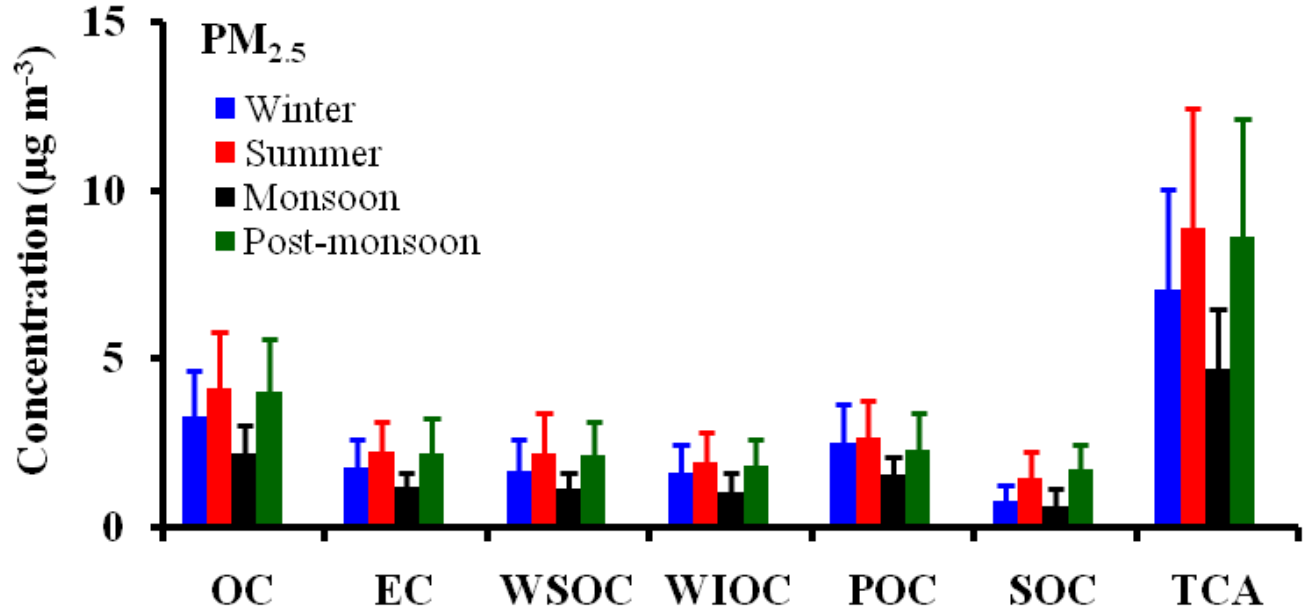

599

600

601

602

603

604

605

606

607

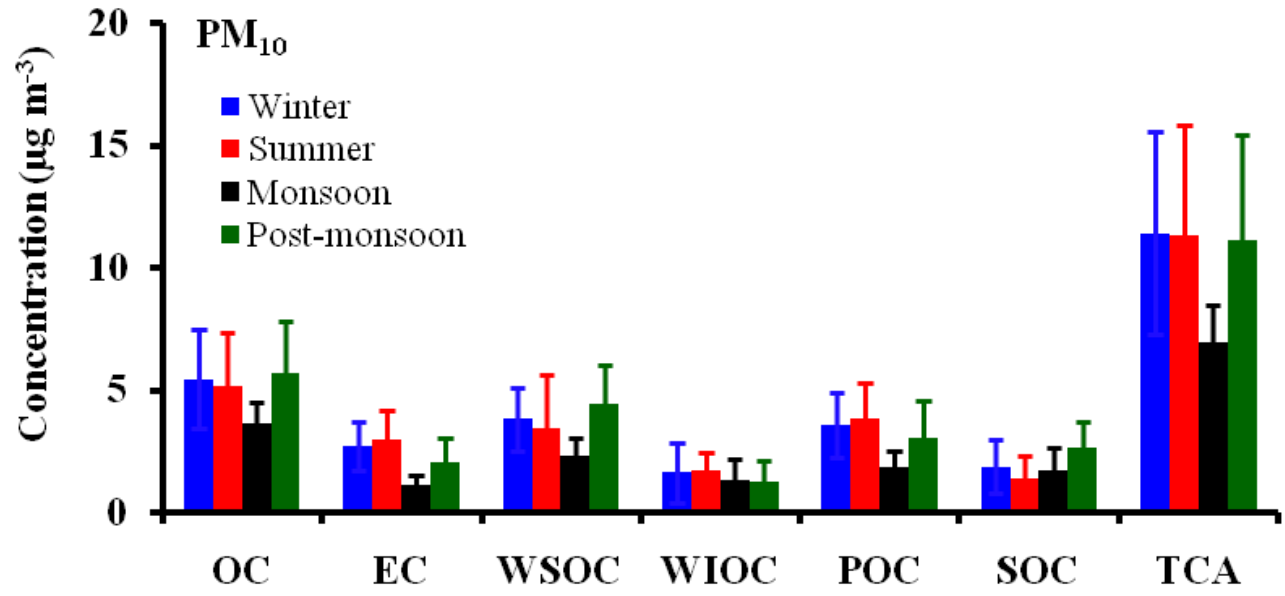

608

609

Fig. 3: Average concentrations of carbonaceous species of $\mathrm{PM}_{2.5}$ and $\mathrm{PM}_{10}$ during winter, summer, monsoon and post-monsoon seasons at Darjeeling.

611

612

613

614 


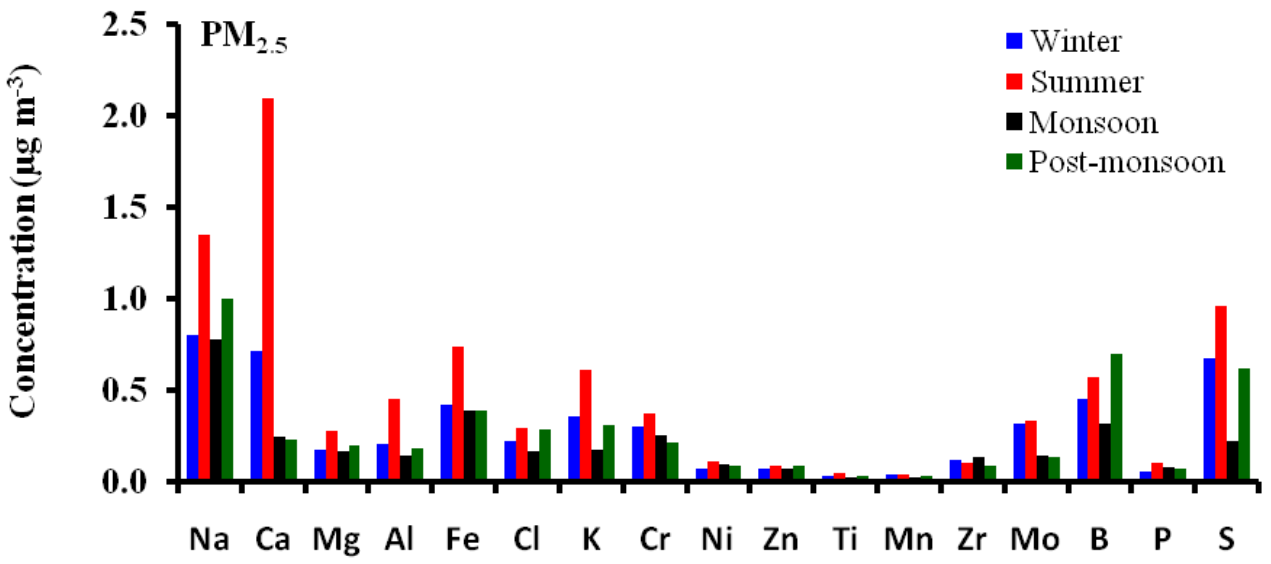

623

624

625

631 Fig. 4: Average concentrations of major and trace elements in $\mathrm{PM}_{2.5}$ and $\mathrm{PM}_{10}$ during winter, summer, monsoon and 632 post-monsoon seasons at Darjeeling. 

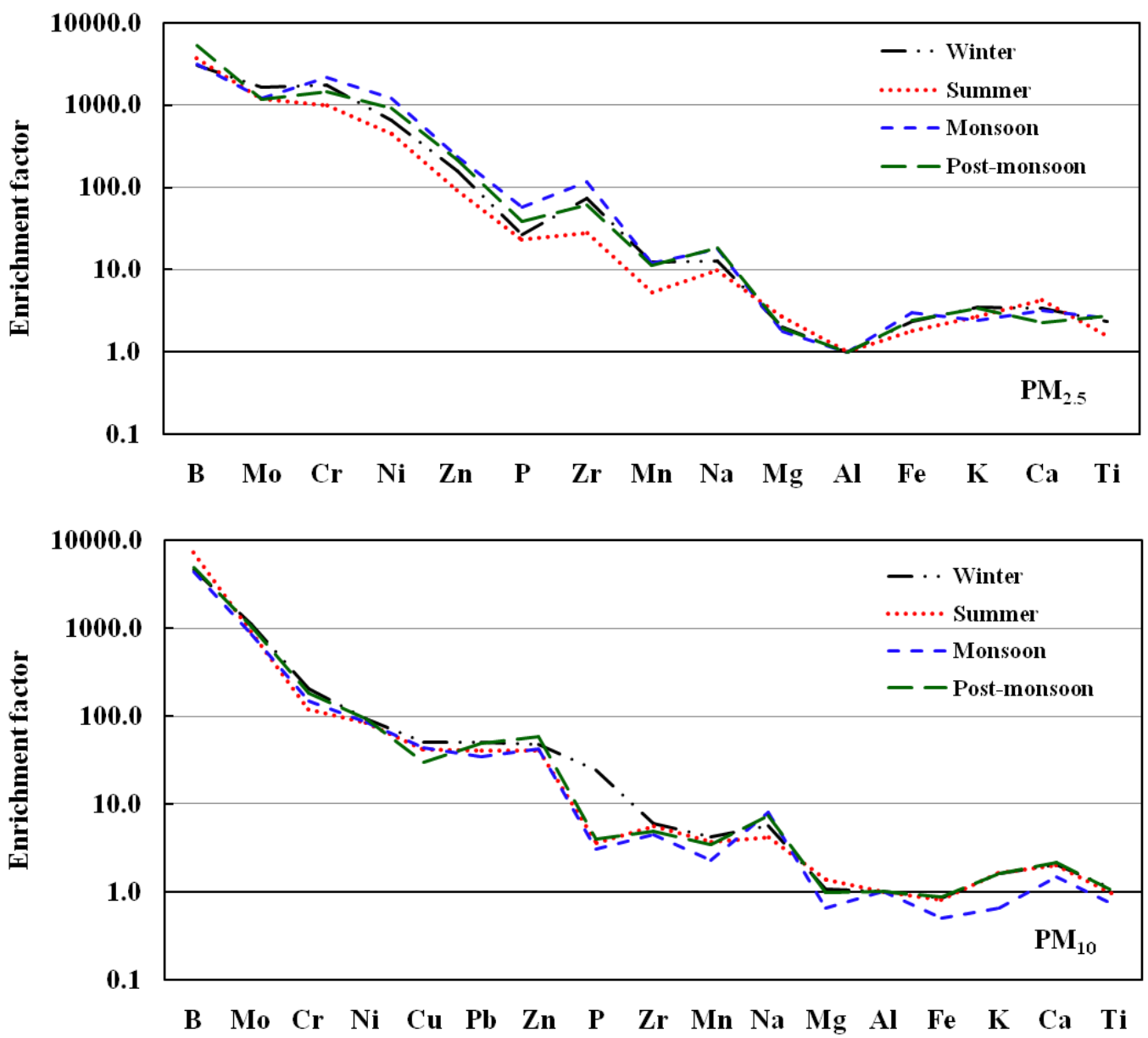

652

653 Fig. 5: Enrichment factor of trace elements of $\mathrm{PM}_{2.5}$ and $\mathrm{PM}_{10}$ during winter, summer, monsoon and post-monsoon 654 seasons at Darjeeling. 
(a)

658

659

660

661

662

663

664

665

666

667

668

669

670

671

672

673

674

675

676

677

678

679

Fig. 6: Five day air mass backward trajectory at sampling site at (a) $100 \mathrm{~m}$, (b) 500m, and (c) $1000 \mathrm{~m}$ AGL during winter, summer (pre-monsoon), monsoon and post-monsoon seasons.

(b)
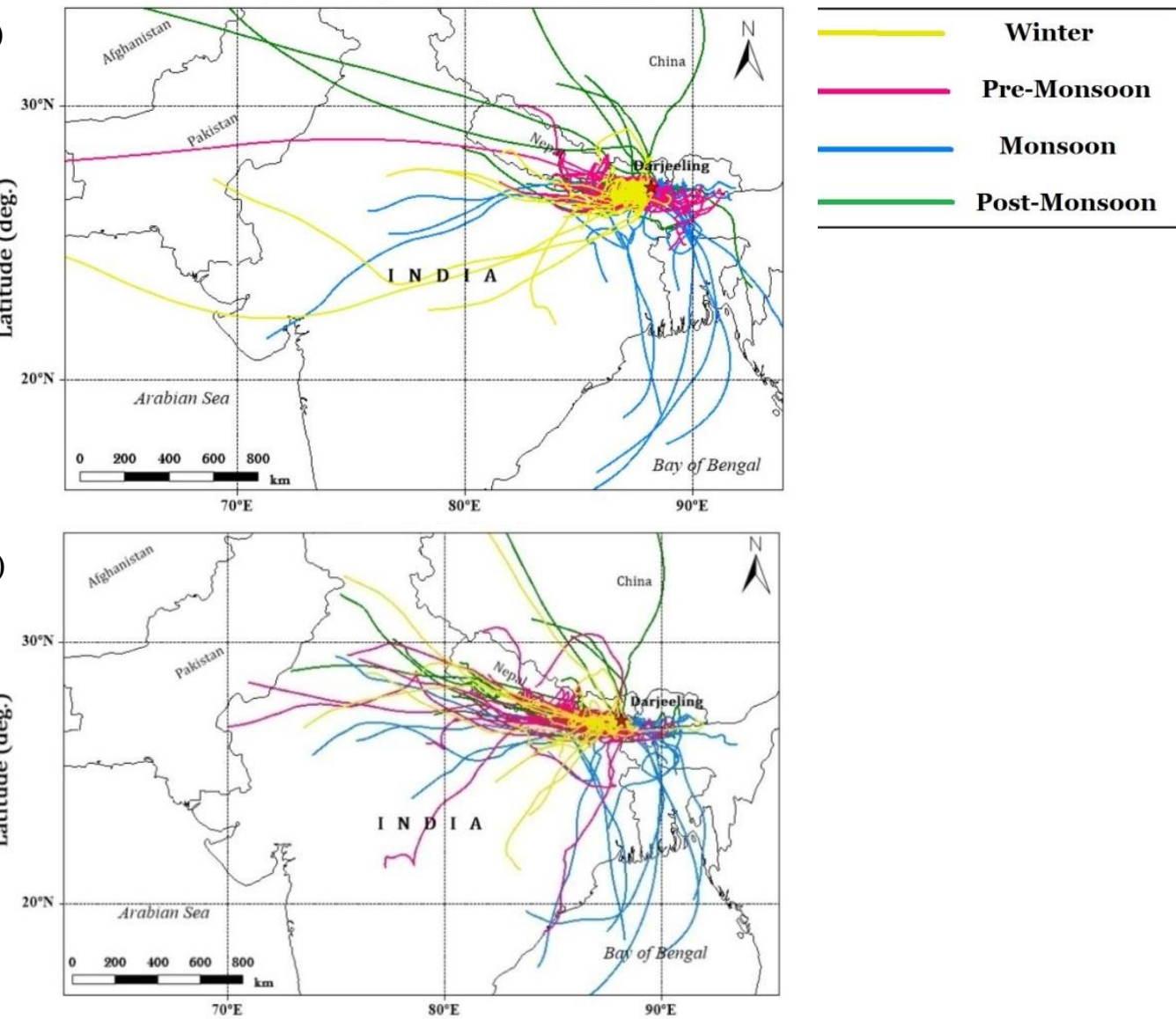

(c)

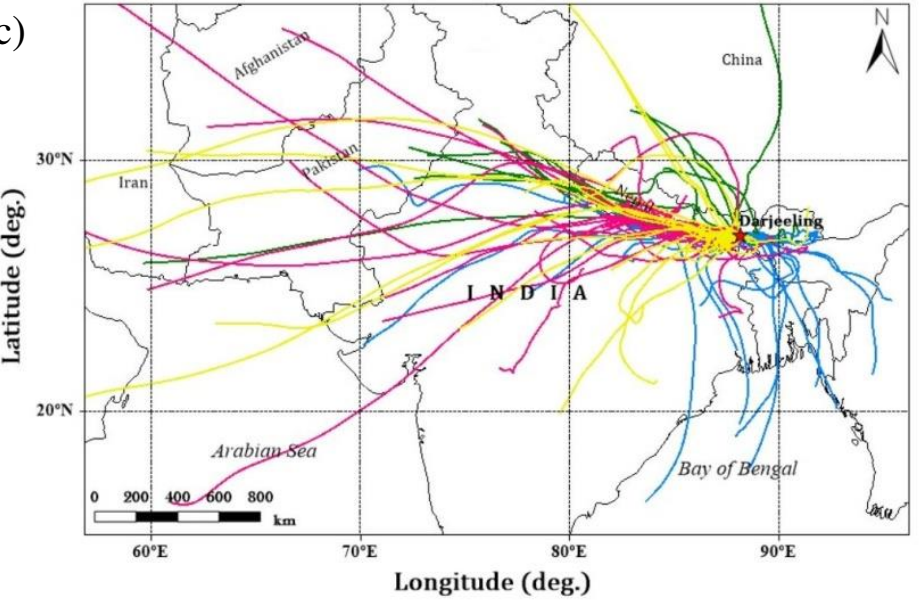


Table 1. Annual average and seasonal concentrations of $\mathrm{PM}_{2.5}$ and $\mathrm{PM}_{10}$ and their chemical species $\left(\mu \mathrm{g} \mathrm{m}^{-3}\right)$ in Darjeeling.

\begin{tabular}{|c|c|c|c|c|c|c|c|c|c|c|}
\hline \multirow[t]{2}{*}{ Species } & \multicolumn{2}{|l|}{ Annual } & \multicolumn{2}{|l|}{ Winter } & \multicolumn{2}{|l|}{ Summer } & \multicolumn{2}{|l|}{ Monsoon } & \multicolumn{2}{|c|}{ Post monsoon } \\
\hline & $\mathbf{P M}_{2.5}$ & $\mathbf{P M}_{10}$ & $\mathbf{P M}_{2.5}$ & $\mathbf{P M}_{10}$ & $\mathbf{P M}_{2.5}$ & $\mathbf{P M}_{10}$ & $\mathbf{P M}_{2.5}$ & $\mathbf{P M}_{10}$ & $\mathbf{P M}_{2.5}$ & $\mathbf{P M}_{10}$ \\
\hline PM & $37 \pm 12$ & $56 \pm 18$ & $31 \pm 9$ & $51 \pm 17$ & $41 \pm 14$ & $64 \pm 20$ & $38 \pm 8$ & $52 \pm 11$ & $40 \pm 11.4$ & $55 \pm 17$ \\
\hline OC & $3.56 \pm 1.59$ & $5.06 \pm 2.03$ & $3.29 \pm 1.37$ & $5.43 \pm 2.02$ & $4.04 \pm 1.67$ & $5.18 \pm 2.14$ & $2.21 \pm 0.86$ & $3.62 \pm 0.87$ & $4.07 \pm 1.55$ & $5.69 \pm 2.09$ \\
\hline $\mathrm{EC}$ & $1.93 \pm 0.93$ & $2.34 \pm 1.18$ & $1.80 \pm 0.81$ & $2.72 \pm 1.01$ & $2.23 \pm 0.92$ & $3.01 \pm 1.15$ & $1.21 \pm 0.43$ & $1.25 \pm 0.38$ & $2.19 \pm 1.06$ & $2.05 \pm 1.02$ \\
\hline WSOC & $1.88 \pm 1.05$ & $3.55 \pm 1.75$ & $1.66 \pm 0.95$ & $3.80 \pm 1.28$ & $2.15 \pm 1.19$ & $3.43 \pm 2.19$ & $1.14 \pm 0.51$ & $2.31 \pm 0.77$ & $2.17 \pm 0.98$ & $4.44 \pm 1.55$ \\
\hline WIOC & $1.69 \pm 0.85$ & $1.51 \pm 0.92$ & $1.63 \pm 0.85$ & $1.63 \pm 1.21$ & $1.94 \pm 0.91$ & $1.75 \pm 0.68$ & $1.07 \pm 0.55$ & $1.31 \pm 0.90$ & $1.86 \pm 0.78$ & $1.25 \pm 0.85$ \\
\hline POC & $2.35 \pm 1.06$ & $3.18 \pm 1.31$ & $2.52 \pm 1.13$ & $3.56 \pm 1.31$ & $2.68 \pm 1.10$ & $3.82 \pm 1.46$ & $1.57 \pm 0.56$ & $1.87 \pm 1.31$ & $2.30 \pm 1.12$ & $3.07 \pm 1.52$ \\
\hline SOC & $1.19 \pm 0.57$ & $2.05 \pm 0.98$ & $0.77 \pm 0.51$ & $1.87 \pm 1.08$ & $1.48 \pm 0.76$ & $1.37 \pm 0.98$ & $0.64 \pm 0.54$ & $1.75 \pm 0.91$ & $1.74 \pm 0.74$ & $2.62 \pm 1.11$ \\
\hline TCA & $7.63 \pm 3.43$ & $10.43 \pm 4.25$ & $7.06 \pm 2.97$ & $11.41 \pm 4.14$ & $8.89 \pm 3.54$ & $11.29 \pm 4.51$ & $4.74 \pm 1.73$ & $6.94 \pm 1.55$ & $8.65 \pm 3.47$ & $11.15 \pm 4.25$ \\
\hline $\mathrm{Na}$ & $1.014 \pm 0.392$ & $0.607 \pm 0.395$ & $0.801 \pm 0.247$ & $0.525 \pm 0.343$ & $1.351 \pm 0.437$ & $0.776 \pm 0.484$ & $0.780 \pm 0.272$ & $0.573 \pm 0.389$ & $1.002 \pm 0.243$ & $0.501 \pm 0.239$ \\
\hline $\mathrm{Mg}$ & $0.209 \pm 0.075$ & $0.244 \pm 0.108$ & $0.172 \pm 0.044$ & $0.237 \pm 0.066$ & $0.279 \pm 0.073$ & $0.191 \pm 0.160$ & $0.168 \pm 0.052$ & $0.103 \pm 0.080$ & $0.195 \pm 0.062$ & $0.123 \pm 0.041$ \\
\hline $\mathrm{Ca}$ & $0.918 \pm 0.813$ & $0.985 \pm 0.299$ & $0.716 \pm 0.504$ & $0.972 \pm 0.178$ & $2.097 \pm 0.706$ & $1.051 \pm 0.442$ & $0.249 \pm 0.213$ & $0.871 \pm 0.232$ & $0.229 \pm 0.213$ & $1.007 \pm 0.182$ \\
\hline $\mathrm{Cl}$ & $0.250 \pm 0.147$ & $0.223 \pm 0.140$ & $0.221 \pm 0.127$ & $0.274 \pm 0.126$ & $0.291 \pm 0.149$ & $0.171 \pm 0.054$ & $0.170 \pm 0.050$ & $0.206 \pm 0.092$ & $0.283 \pm 0.180$ & $0.244 \pm 0.118$ \\
\hline $\mathrm{P}$ & $0.078 \pm 0.037$ & $0.077 \pm 0.034$ & $0.054 \pm 0.029$ & $0.212 \pm 0.179$ & $0.105 \pm 0.026$ & $0.033 \pm 0.024$ & $0.081 \pm 0.034$ & $0.032 \pm 0.013$ & $0.070 \pm 0.039$ & $0.033 \pm 0.009$ \\
\hline S & $0.667 \pm 0.404$ & $1.260 \pm 0.744$ & $0.675 \pm 0.382$ & $1.277 \pm 0.768$ & $0.956 \pm 0.370$ & $1.680 \pm 0.744$ & $0.223 \pm 0.181$ & $0.771 \pm 0.495$ & $0.620 \pm 0.284$ & $1.098 \pm 0.629$ \\
\hline K & $0.388 \pm 0.224$ & $0.650 \pm 0.376$ & $0.360 \pm 0.110$ & $0.699 \pm 0.295$ & $0.608 \pm 0.226$ & $0.774 \pm 0.435$ & $0.174 \pm 0.050$ & $0.353 \pm 0.242$ & $0.307 \pm 0.171$ & $0.681 \pm 0.346$ \\
\hline $\mathrm{Al}$ & $0.261 \pm 0.164$ & $0.922 \pm 0.446$ & $0.203 \pm 0.104$ & $0.860 \pm 0.291$ & $0.454 \pm 0.143$ & $0.943 \pm 0.661$ & $0.143 \pm 0.065$ & $1.061 \pm 0.386$ & $0.179 \pm 0.068$ & $0.845 \pm 0.215$ \\
\hline $\mathrm{Fe}$ & $0.502 \pm 0.195$ & $0.635 \pm 0.266$ & $0.423 \pm 0.141$ & $0.652 \pm 0.189$ & $0.737 \pm 0.153$ & $0.694 \pm 0.381$ & $0.390 \pm 0.087$ & $0.482 \pm 0.188$ & $0.391 \pm 0.067$ & $0.663 \pm 0.142$ \\
\hline $\mathrm{Ti}$ & $0.035 \pm 0.015$ & $0.057 \pm 0.022$ & $0.031 \pm 0.009$ & $0.061 \pm 0.017$ & $0.047 \pm 0.013$ & $0.058 \pm 0.031$ & $0.024 \pm 0.008$ & $0.049 \pm 0.016$ & $0.032 \pm 0.018$ & $0.056 \pm 0.013$ \\
\hline $\mathrm{Cr}$ & $0.291 \pm 0.143$ & $0.122 \pm 0.114$ & $0.299 \pm 0.102$ & $0.146 \pm 0.125$ & $0.372 \pm 0.199$ & $0.093 \pm 0.014$ & $0.254 \pm 0.081$ & $0.132 \pm 0.032$ & $0.215 \pm 0.074$ & $0.122 \pm 0.114$ \\
\hline $\mathrm{Ni}$ & $0.092 \pm 0.025$ & $0.084 \pm 0.008$ & $0.072 \pm 0.012$ & $0.044 \pm 0.008$ & $0.110 \pm 0.027$ & $0.045 \pm 0.006$ & $0.094 \pm 0.014$ & $0.049 \pm 0.007$ & $0.090 \pm 0.021$ & $0.043 \pm 0.011$ \\
\hline $\mathrm{Cu}$ & - & $0.028 \pm 0.014$ & - & $0.032 \pm 0.008$ & - & $0.029 \pm 0.005$ & - & $0.034 \pm 0.026$ & - & $0.018 \pm 0.004$ \\
\hline $\mathrm{Zn}$ & $0.079 \pm 0.032$ & $0.092 \pm 0.033$ & $0.069 \pm 0.035$ & $0.088 \pm 0.032$ & $0.088 \pm 0.035$ & $0.081 \pm 0.027$ & $0.072 \pm 0.016$ & $0.097 \pm 0.038$ & $0.084 \pm 0.031$ & $0.105 \pm 0.034$ \\
\hline $\mathrm{Mn}$ & $0.033 \pm 0.012$ & $0.048 \pm 0.018$ & $0.037 \pm 0.010$ & $0.055 \pm 0.013$ & $0.037 \pm 0.010$ & $0.053 \pm 0.016$ & $0.033 \pm 0.012$ & $0.036 \pm 0.015$ & $0.031 \pm 0.015$ & $0.044 \pm 0.021$ \\
\hline Mo & $0.245 \pm 0.169$ & $0.060 \pm 0.013$ & $0.318 \pm 0.236$ & $0.063 \pm 0.010$ & $0.337 \pm 0.224$ & $0.058 \pm 0.013$ & $0.144 \pm 0.034$ & $0.061 \pm 0.014$ & $0.133 \pm 0.028$ & $0.058 \pm 0.015$ \\
\hline $\mathrm{Zr}$ & $0.107 \pm 0.094$ & $0.061 \pm 0.013$ & $0.117 \pm 0.099$ & $0.041 \pm 0.009$ & $0.102 \pm 0.039$ & $0.042 \pm 0.012$ & $0.132 \pm 0.112$ & $0.038 \pm 0.016$ & $0.086 \pm 0.026$ & $0.033 \pm 0.011$ \\
\hline $\mathrm{Pb}$ & - & $0.076 \pm 0.064$ & - & $0.084 \pm 0.010$ & - & $0.072 \pm 0.069$ & - & $0.069 \pm 0.059$ & - & $0.079 \pm 0.067$ \\
\hline $\mathrm{B}$ & $0.533 \pm 0.389$ & $0.376 \pm 0.220$ & $0.455 \pm 0.179$ & $0.302 \pm 0.174$ & $0.575 \pm 0.324$ & $0.510 \pm 0.262$ & $0.321 \pm 0.096$ & $0.343 \pm 0.203$ & $0.702 \pm 0.472$ & $0.307 \pm 0.132$ \\
\hline
\end{tabular}

\pm Standard deviation (at $1 \sigma$ ) 
Table 2. PCA factor loading of $\mathrm{PM}_{2.5}$ and $\mathrm{PM}_{10}$ samples in Darjeeling, India.

\begin{tabular}{|c|c|c|c|c|c|c|c|c|}
\hline \multirow[t]{2}{*}{ Species } & \multicolumn{4}{|c|}{$\mathrm{PM}_{2.5}$} & \multicolumn{4}{|c|}{$\mathbf{P M}_{10}$} \\
\hline & Factor 1 & Factor 2 & Factor 3 & Factor 4 & Factor 1 & Factor 2 & Factor 3 & Factor 4 \\
\hline $\mathrm{OC}$ & 0.942 & 0.159 & 0.482 & 0.013 & 0.262 & 0.912 & 0.416 & 0.046 \\
\hline WSOC & 0.872 & 0.095 & 0.029 & - & 0.197 & 0.856 & 0.174 & 0.092 \\
\hline $\mathrm{EC}$ & 0.563 & 0.138 & 0.743 & 0.126 & 0.182 & 0.846 & 0.586 & 0.186 \\
\hline $\mathrm{Na}$ & 0.139 & 0.735 & 0.031 & - & 0.851 & 0.063 & 0.162 & 0.142 \\
\hline $\mathrm{Mg}$ & 0.056 & 0.832 & 0.048 & 0.061 & 0.909 & 0.188 & 0.083 & 0.098 \\
\hline $\mathrm{Ca}$ & 0.035 & 0.877 & 0.229 & 0.233 & 0.935 & 0.196 & 0.049 & - \\
\hline $\mathrm{Al}$ & 0.219 & 0.898 & 0.198 & 0.191 & 0.860 & 0.126 & 0.074 & 0.368 \\
\hline $\mathrm{Fe}$ & 0.132 & 0.852 & 0.031 & 0.282 & 0.882 & 0.294 & - & 0.064 \\
\hline $\mathrm{Ti}$ & 0.383 & 0.497 & 0.052 & - & 0.866 & 0.257 & 0.067 & 0.032 \\
\hline K & 0.608 & 0.588 & 0.316 & 0.097 & 0.628 & 0.696 & 0.010 & 0.055 \\
\hline $\mathrm{Cl}$ & 0.636 & 0.137 & - & 0.394 & 0.072 & 0.853 & 0.389 & 0.095 \\
\hline $\mathrm{P}$ & 0.075 & 0.594 & 0.160 & 0.283 & 0.107 & - & 0.964 & 0.068 \\
\hline S & 0.574 & 0.348 & 0.237 & 0.361 & 0.468 & 0.623 & - & 0.274 \\
\hline $\mathrm{Cr}$ & 0.061 & 0.138 & 0.235 & 0.760 & 0.065 & - & 0.468 & 0.674 \\
\hline $\mathrm{Ni}$ & - & 0.029 & 0.740 & 0.396 & 0.185 & - & 0.235 & 0.704 \\
\hline $\mathrm{Cu}$ & - & - & - & - & 0.109 & - & 0.425 & 0.838 \\
\hline $\mathrm{Zn}$ & 0.281 & 0.102 & 0.754 & 0.467 & 0.216 & 0.013 & 0.530 & 0.619 \\
\hline $\mathrm{Mn}$ & - & 0.120 & 0.436 & 0.701 & 0.197 & 0.056 & 0.140 & 0.364 \\
\hline Mo & 0.101 & 0.087 & 0.891 & 0.069 & - & - & 0.037 & 0.876 \\
\hline $\mathrm{Zr}$ & - & - & 0.266 & 0.701 & - & - & 0.010 & 0.246 \\
\hline $\mathrm{Pb}$ & - & - & - & - & - & 0.063 & 0.273 & 0.273 \\
\hline B & 0.106 & - & 0.730 & 0.016 & 0.523 & 0.152 & 0.428 & 0.428 \\
\hline$\%$ Variance & 38.5 & 17.6 & 11.6 & 8.7 & 36.7 & 16.2 & 12.4 & 10.8 \\
\hline Cumulative variance $(\%)$ & 38.3 & 55.9 & 67.5 & 76.2 & 36.7 & 52.9 & 65.3 & 76.1 \\
\hline Sources & $\mathrm{BB}+\mathrm{FFC}$ & Crustal/SD & VE & IE & Crustal/SD & $\mathrm{BB}+\mathrm{FFC}$ & VE & IE \\
\hline
\end{tabular}

Extraction method: principal component analysis; rotation method: Varimax with Kaiser Normalization; Eigenvalue >1.00; factor loading $\geq 0.40$.

BB: biomass burning; FFC: fossil fuel combustion; SD: soil dust; VE: vehicular emissions; IE: industrial emission. 


\section{Figures}

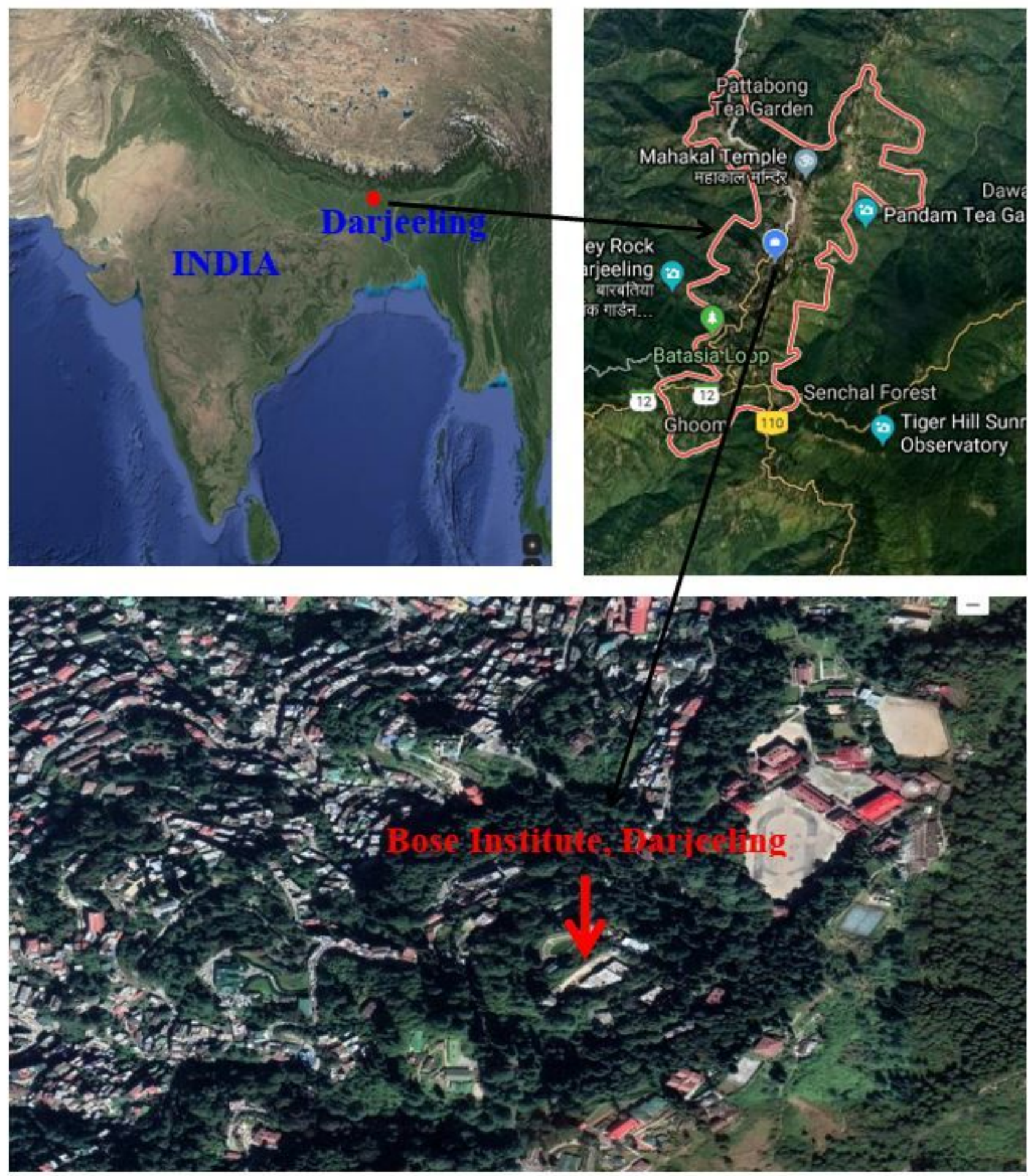

Figure 1

Map of the observational site (Source: Google maps). 


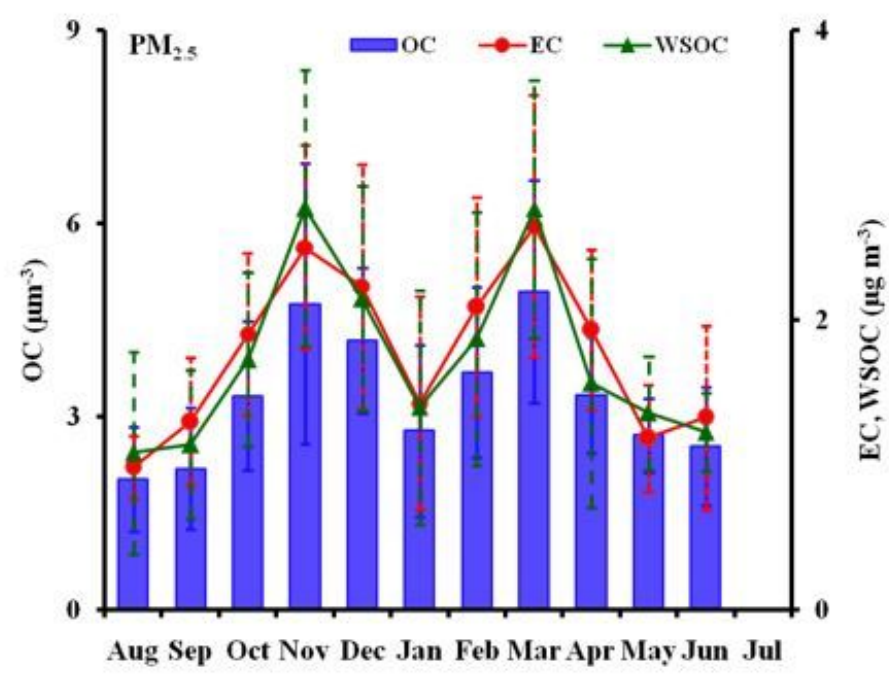

2018-2019

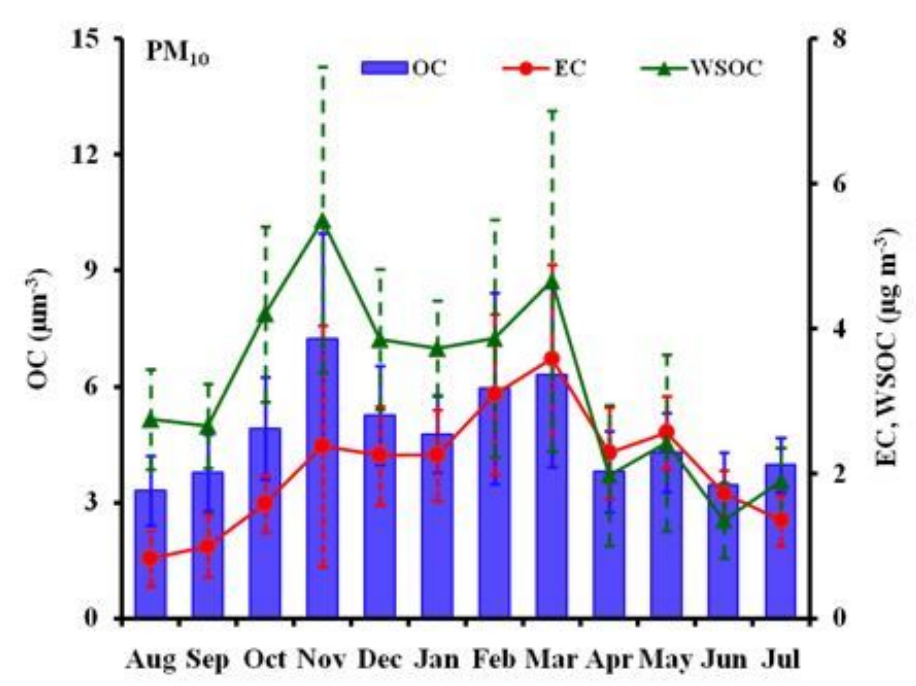

2018-2019

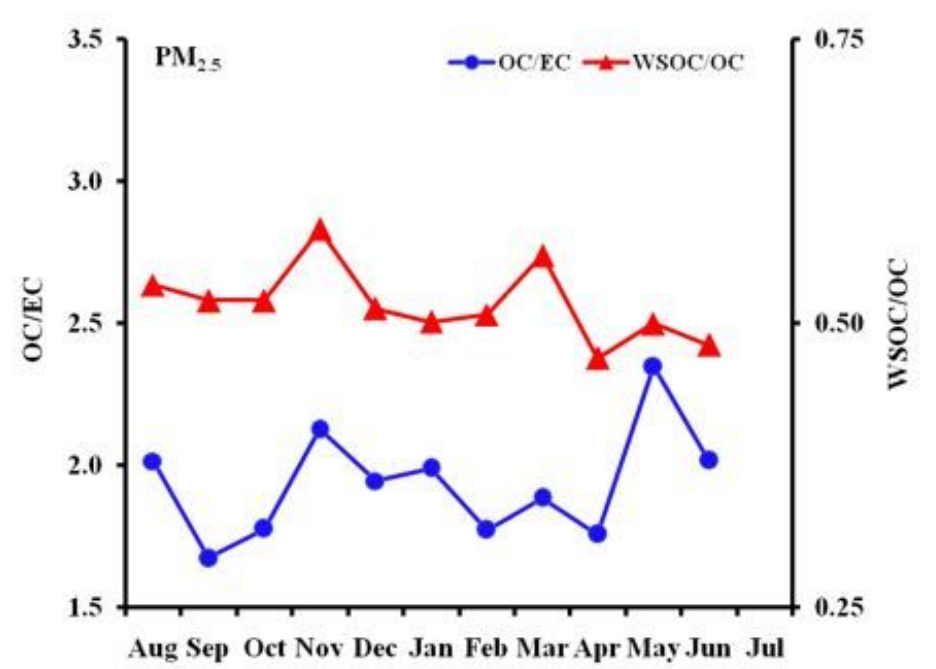

2018-2019

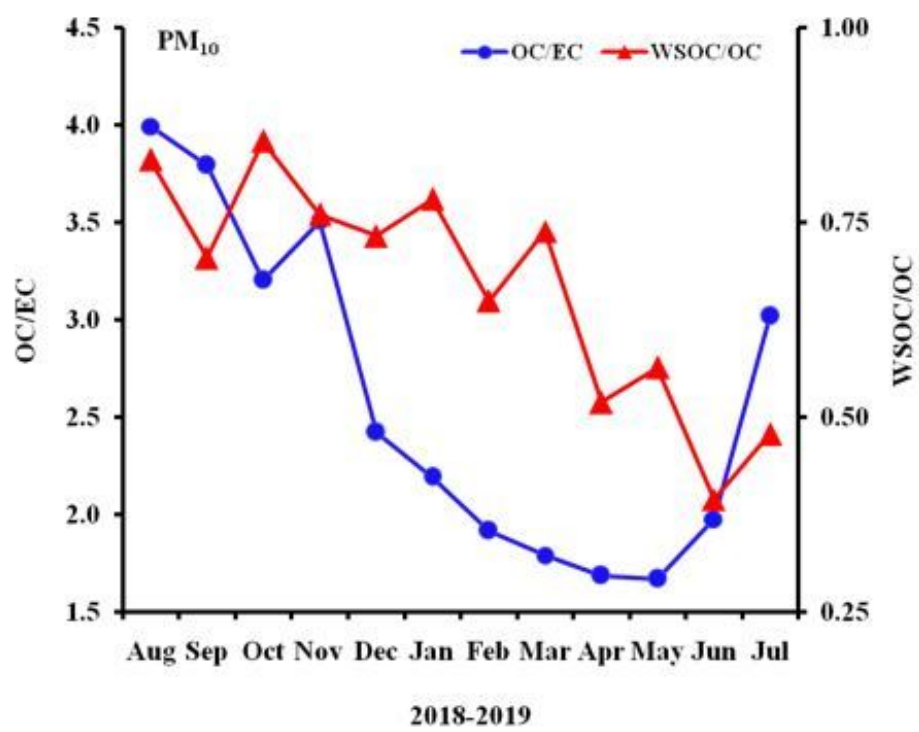

Figure 2

Monthly average concentrations of OC, EC and WSOC and their mass ratios of PM2.5 and PM10 at Darjeeling. 

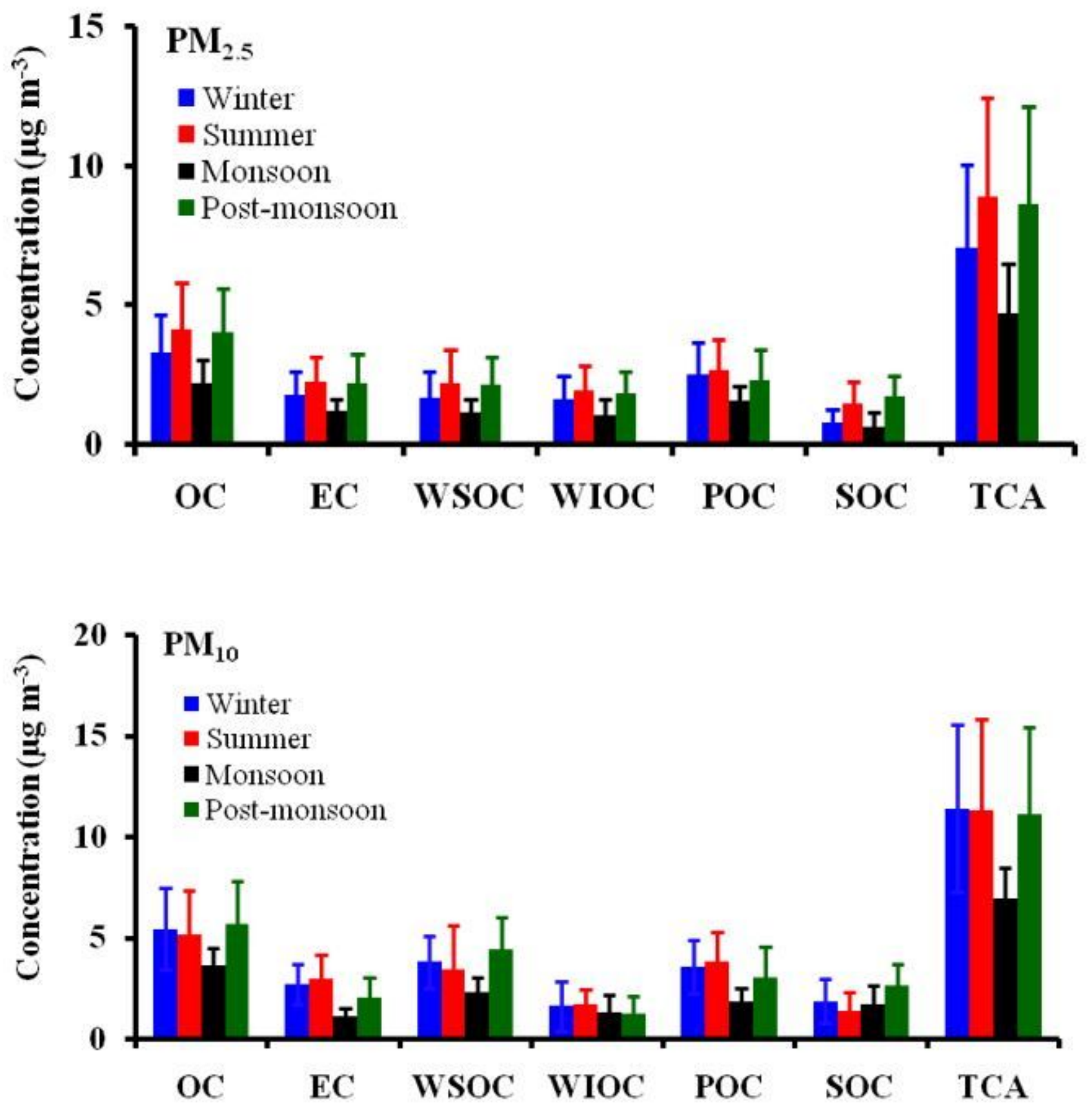

Figure 3

Average concentrations of carbonaceous species of PM2.5 and PM10 during winter, summer, monsoon and post-monsoon seasons at Darjeeling. 

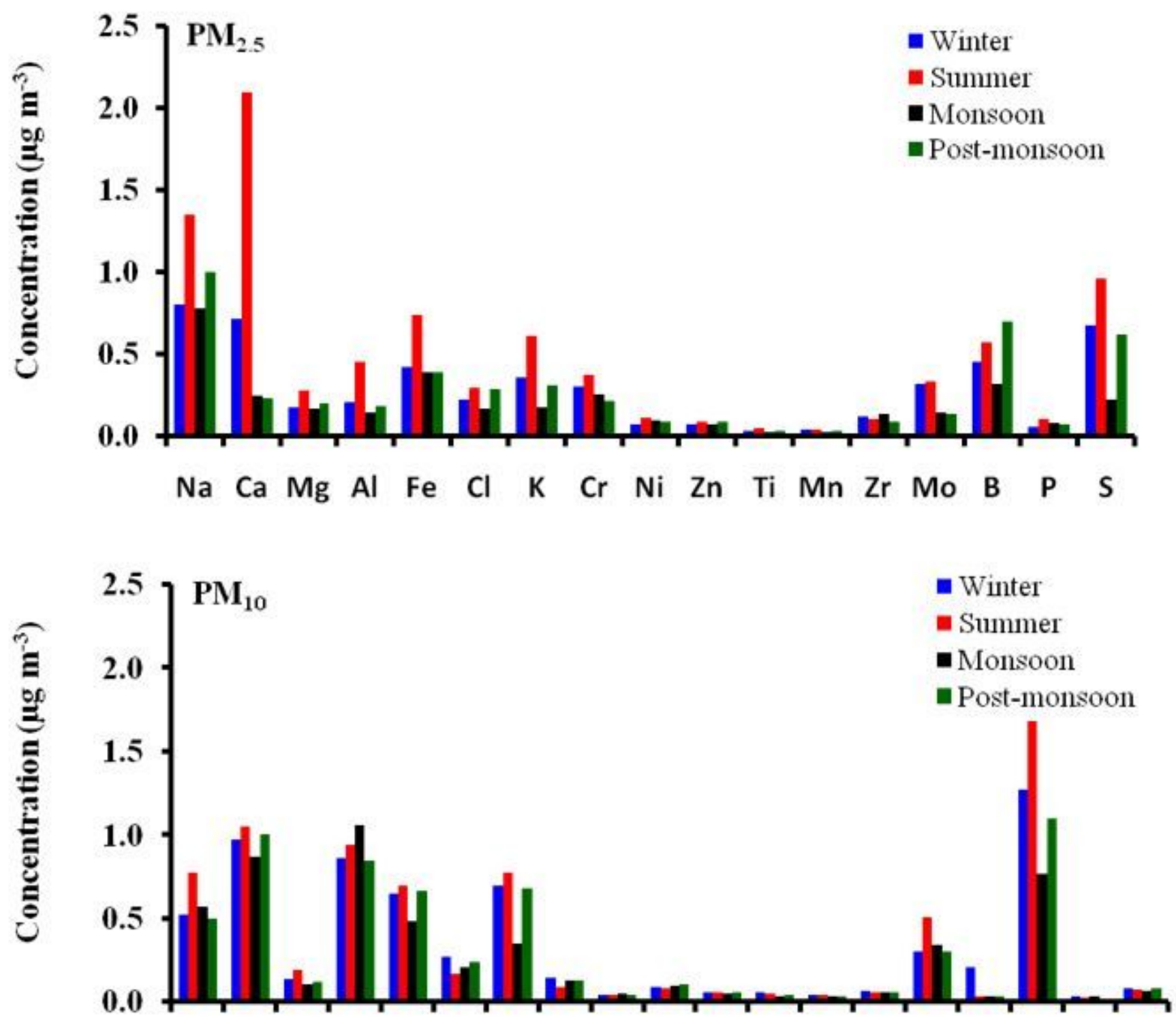

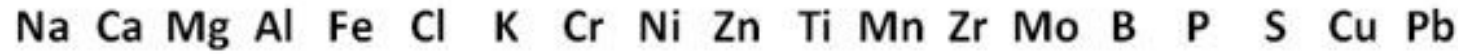

Figure 4

Average concentrations of major and trace elements in PM2.5 and PM10 during winter, summer, monsoon and post-monsoon seasons at Darjeeling 


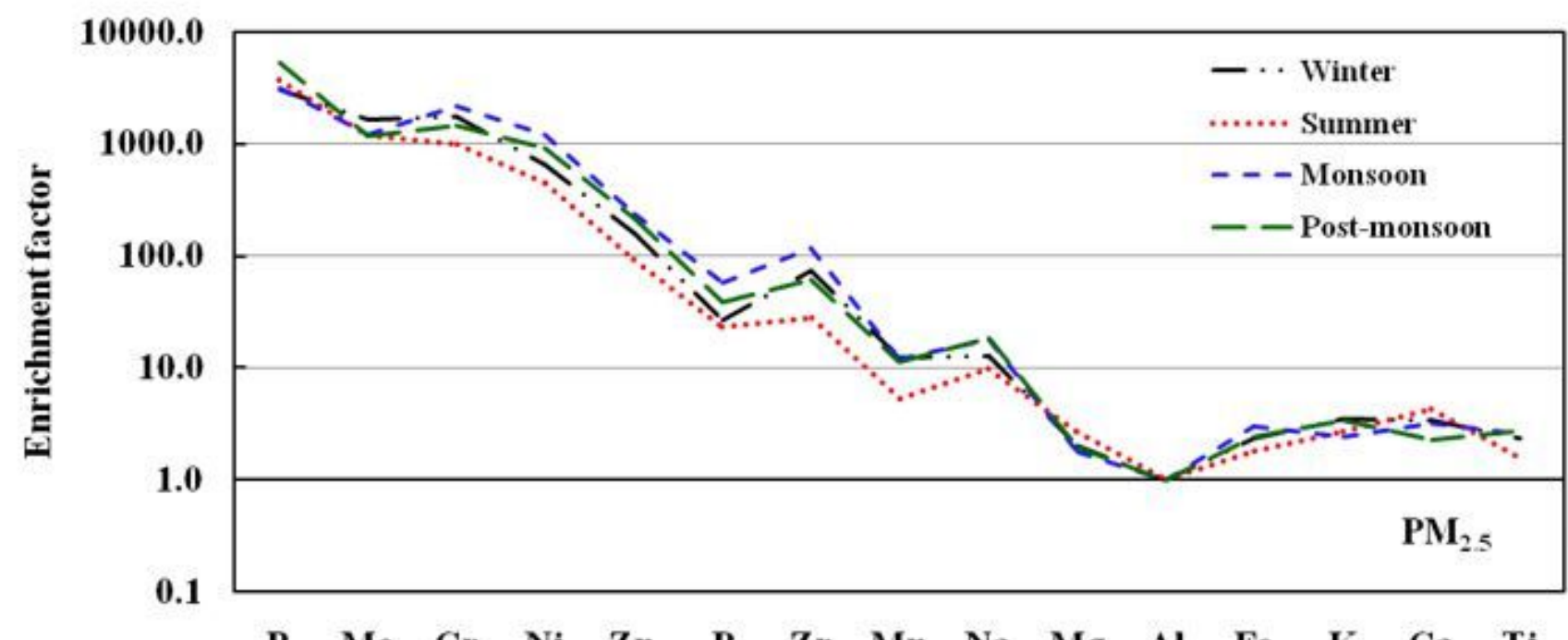

$\begin{array}{lllllllllllllll}\text { B } & \text { Mo } & \mathrm{Cr} & \mathrm{Ni} & \mathrm{Zn} & \mathrm{P} & \mathrm{Zr} & \mathrm{Mn} & \mathrm{Na} & \mathrm{Mg} & \mathrm{Al} & \mathrm{Fe} & \mathrm{K} & \mathrm{Ca} & \mathrm{Ti}\end{array}$

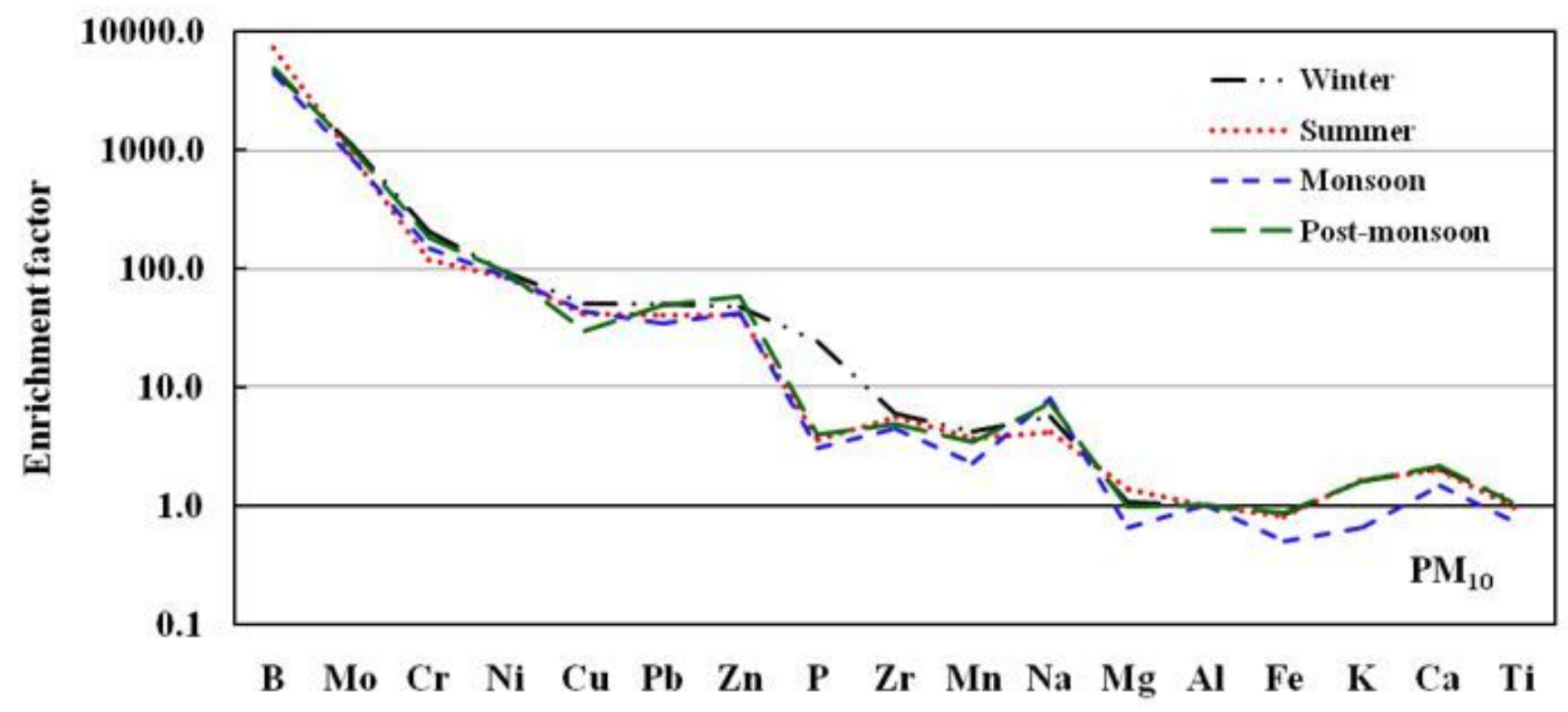

Figure 5

Enrichment factor of trace elements of PM2.5 and PM10 during winter, summer, monsoon and postmonsoon seasons at Darjeeling. 
(a)
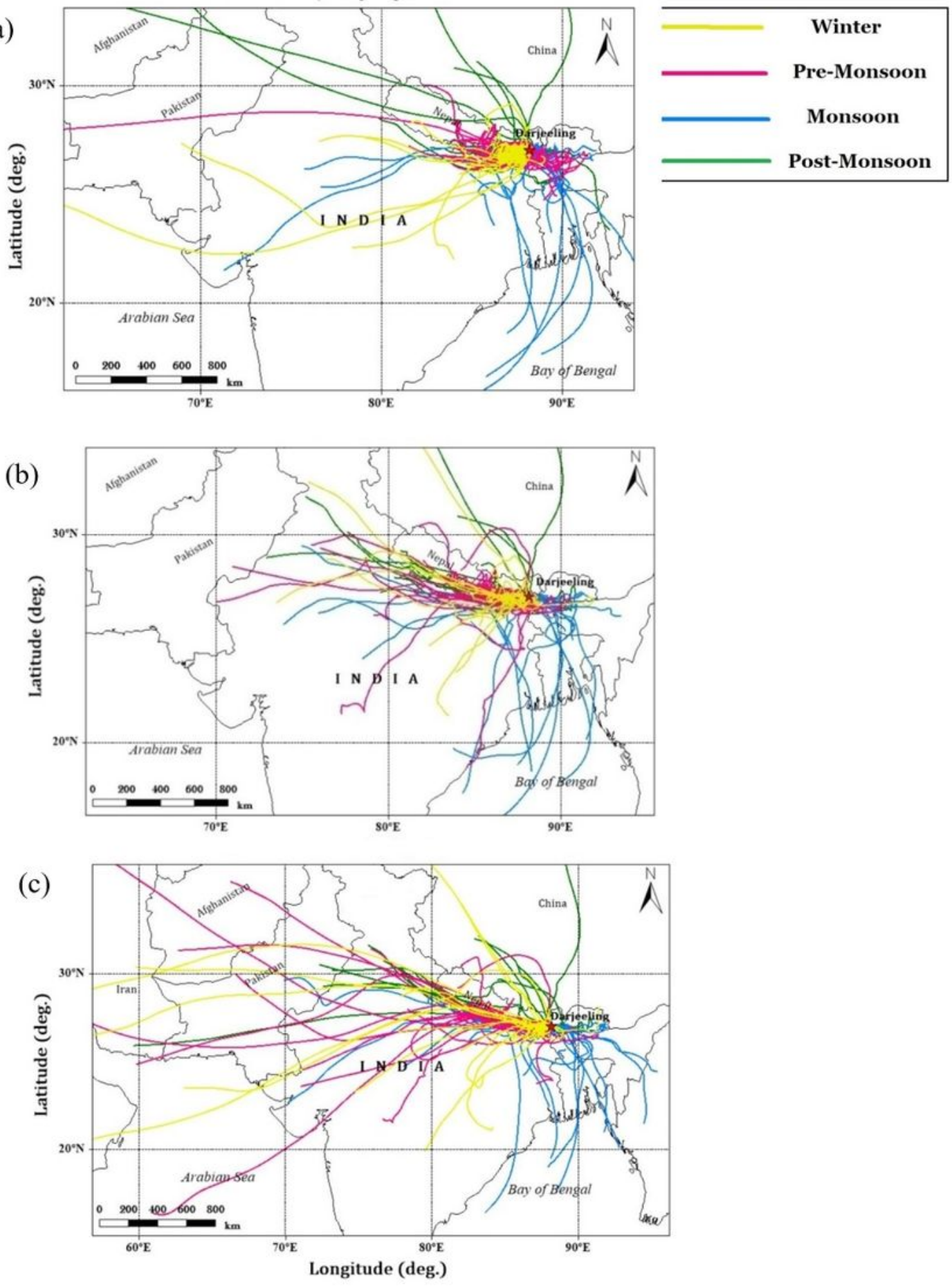

\section{Figure 6}

Five day air mass backward trajectory at sampling site at (a) 100m, (b) 500m, and (c) $1000 \mathrm{~m}$ AGL during winter, summer (pre-monsoon), monsoon and post-monsoon seasons.

\section{Supplementary Files}


This is a list of supplementary files associated with this preprint. Click to download.

- SupplementaryInformation.docx 